Fabric, paleomagnetism, and interpretation of pre-illinoian diamictons and paleosols on Cloudy Ridge and Milk River Ridge, Alberta and Montana

\author{
Orientation, paléomagnétisme et interprétation des diamictons \\ et des paléosols du pré-Illinoien provenant du Cloudy Ridge et \\ du Milk River Ridge, en Alberta et au Montana \\ Orientación, paleomagnetismo e interpretación de los \\ diamictones y paleo suelos del pre-illinois provenientes del \\ cloudy ridge y del milk river ridge en Alberta y Montana, \\ Canadá
}

Eric T. Karlstrom et Rene W. Barendregt

Volume 55, numéro 2, 2001

URI : https://id.erudit.org/iderudit/008299ar

DOI : https://doi.org/10.7202/008299ar

Aller au sommaire du numéro

Éditeur(s)

Les Presses de l'Université de Montréal

ISSN

0705-7199 (imprimé)

1492-143X (numérique)

Découvrir la revue

Citer cet article

Karlstrom, E. T. \& Barendregt, R. W. (2001). Fabric, paleomagnetism, and interpretation of pre-illinoian diamictons and paleosols on Cloudy Ridge and Milk River Ridge, Alberta and Montana. Géographie physique et Quaternaire, 55(2), 141-157. https://doi.org/10.7202/008299ar
Résumé de l'article

L'orientation des cailloux et leurs caracactéristiques sédimentologiques indiquent que les diamictons du pré-Wisconsinien (Drift de Kennedy) provenant du Cloudy Ridge (Alberta) et du Milk River Ridge (Montana) sont d'origine glaciaire plutôt que colluviale. Les valeurs propres $\mathrm{S}_{1}$ et $\mathrm{S}_{3}$ des unités supérieures dans les deux chaînons sont caractéristiques du till d'accrétion non déformé, tandis que les unités inférieures sont caractéristiques d'un écoulement de sédiments glaciaires. Toutes les autres propriétés, dont les matrices compactes, les stries, l'inclinaison moyenne des cailloux et les projections équivalentes de Schmidt semblent démontrer que chacune des unités est un till d'accrétion ou un till de fond. Les propriétés pédogénétiques indiquent que les zones d'altération recouvrant les tills sont des paléosols. Le degré de rubéfaction, l'accumulation d'argile, de fer et d'alumimium et l'altération du minéral argileux ressemblent à ceux des sols fortement développés qui se sont formés dans des milieux plus chauds et plus humides. Le raisonnement selon lequel les propriétés " pseudo-pédologiques " de l'unité de Cloudy Ridge résultent d'une diagénèse après enfouissement doit être infirmé puisque des paléosols presque identiques sont présents à la surface du Milk River Ridge et d'autres interfluves vers le sud. Chacune des unités étudiées présente une polarité normale. Selon les comparaisons faites avec des séquences de paléosols et de till similaires apparaissant dans les coupes du Drift de Kennedy situées sur les interfluves avoisinants, le till de Cloudy Ridge et le till supérieur du Milk River Ridge ont probablement été déposés au début ou au cours moyen du chrone polaire normal de Bruhnes (de 780 ka à maintenant) tandis que le till inférieur du Milk River Ridge date d'une époque antérieure au Brunhes, du sous-chrone normal d'Olduvai (1,98 à 1,76 Ma) ou du chrone polaire normal de Gauss (3,6 à 2,6 Ma). 


\section{FABRIC, PALEOMAGNETISM, AND INTERPRETATION OF PRE-ILLINOIAN DIAMICTONS AND PALEOSOLS ON CLOUDY RIDGE AND MILK RIVER RIDGE, ALBERTA AND MONTANA}

Eric T. KARLSTROM* and Rene W. BARENDREGT, Department of Anthropology and Geography, California State University, Stanislaus, Turlock, California 95382, U.S.A., and Department of Geography, University of Lethbridge, Lethbridge, Alberta T1K 3M4.

ABSTRACT Pebble fabrics and sedimentological properties indicate that pre-Wisconsinan diamictons (Kennedy Drift) on Cloudy Ridge (Alberta) and Milk River Ridge (Montana) are of glacial rather than colluvial origin. $S_{1}$ and $\mathrm{S}_{3}$ eigenvalues of the upper units on the two ridges are typical of undeformed lodgement till whereas those of the lower unit on Milk River Ridge are typical of glacigenic sediment flow. Other properties, including compact matrices, striations on stones, mean pebble dip angles, and Schmidt equal-area stereonet patterns, suggest each unit is lodgement or basal till. Pedogenic features indicate weathering zones capping the tills are paleosols. Degree of rubification, clay, iron and aluminum buildup, and clay mineral alteration resembles those of very strongly developed soils formed in warmer and moister environments. The argument that "soil-like features" of the Cloudy Ridge unit resulted from postburial diagenesis is disproven because nearly identical paleosols occur at the surface on Milk River Ridge and other interfluves to the south. Each unit examined has normal polarity. Based on comparisons with similar till/paleosol sequences exposed in Kennedy Drift sections on nearby interfluves, the Cloudy Ridge till and the upper till on Milk River Ridge were probably deposited during the early to middle Bruhnes Normal Chron (780 ka to present) whereas the lower till on Milk River Ridge is of earlier Brunhes age or dates back to the Olduvai (1.98 to $1.76 \mathrm{Ma}$ ) Normal Subchron or the Gauss Normal Chron (3.6 to $2.6 \mathrm{Ma}$ ).

RÉSUMÉ Orientation, paléomagnétisme et interprétation des diamictons et des paléosols du pré-Illinoien provenant du Cloudy Ridge et du Milk River Ridge, en Alberta et au Montana. L'orientation des cailloux et leurs caracactéristiques sédimentologiques indiquent que les diamictons du pré-Wisconsinien (Drift de Kennedy) provenant du Cloudy Ridge (Alberta) et du Milk River Ridge (Montana) sont d'origine glaciaire plutôt que colluviale. Les valeurs propres $S_{1}$ et $S_{3}$ des unités supérieures dans les deux chaînons sont caractéristiques du till d'accrétion non déformé, tandis que les unités inférieures sont caractéristiques d'un écoulement de sédiments glaciaires. Toutes les autres propriétés, dont les matrices compactes, les stries, l'inclinaison moyenne des cailloux et les projections équivalentes de Schmidt semblent démontrer que chacune des unités est un till d'accrétion ou un till de fond. Les propriétés pédogénétiques indiquent que les zones d'altération recouvrant les tills sont des paléosols. Le degré de rubéfaction, l'accumulation d'argile, de fer et d'alumimium et l'altération du minéral argileux ressemblent à ceux des sols fortement développés qui se sont formés dans des milieux plus chauds et plus humides. Le raisonnement selon lequel les propriétés "pseudo-pédologiques 》 de l'unité de Cloudy Ridge résultent d'une diagénèse après enfouissement doit être infirmé puisque des paléosols presque identiques sont présents à la surface du Milk River Ridge et d'autres interfluves vers le sud. Chacune des unités étudiées présente une polarité normale. Selon les comparaisons faites avec des séquences de paléosols et de till similaires apparaissant dans les coupes du Drift de Kennedy situées sur les interfluves avoisinants, le till de Cloudy Ridge et le till supérieur du Milk River Ridge ont probablement été déposés au début ou au cours moyen du chrone polaire normal de Bruhnes (de 780 ka à maintenant) tandis que le till inférieur du Milk River Ridge date d'une époque antérieure au Brunhes, du sous-chrone normal d'Olduvai $(1,98$ à $1,76 \mathrm{Ma})$ ou du chrone polaire normal de Gauss (3,6 à 2,6 Ma).

Manuscrit reçu le 16 novembre 2000; manuscrit révisé accepté le 16 octobre 2001

*E-mail: estrom @ toto.csustan.edu
RESUMEN Orientación, paleomagnetismo e interpretación de los diamictones y paleo suelos del pre-illinois provenientes del cloudy ridge y del milk river ridge en Alberta y Montana, Canadá. Las propiedades sedimentológicas y la orientación de las rocas indican que los diamicton (Drif de Kennedy) del pre-wisconsiniano en la región de Cloudy Ridge (Alberta) y Milky River Ridge (Montana) son de origen glaciar y no coluvial. Los valores propios $S_{1}$ y $S_{3}$ de las unidades superiores de las dos cadenas de montañas son características de la acumulación de tillitas no deformadas mientras que las de la unidad inferior del Milky River ridge son características de una acumulación de sedimentos glaciares. Otras propiedades, que incluyen la matriz compacta, la estriación de las rocas, el ángulo de inclinación medio de las rocas y las proyecciones equivalentes de Schmidt parecen indicar que cada unidad es ya sea tillitas de acumulación o tillitas basales. Las características pedogénicas indican que las zonas que recubren las tillitas son paleosuelos. El grado de rubificación, de acumulación de arcilla, de hierro y de aluminio así como la alteración de los minerales que la componen, se asemejan a los suelos fuertemente desarrollados formados en ambientes mas cálidos y húmedos. El argumento según el cual las características del «pseudo-suelo» de la unidad del Cloudy Ridge resultan de una diagenesis post-enterrramiento son poco fundadas ya que los paleo suelos casi idénticos están presentes en la superficie del Milky River Ridge y en otras regiones interfluviales hacia el sur. Cada una de las unidades estudiadas presenta una polaridad normal. De acuerdo a las comparaciones hechas entre las secuencias de paleosuelos, tillitas semejantes aparecen en las capas del Drif de Kennedy situadas en las interfluvias aledañas, las tillitas en la región del Cloudy Ridge y de la región superior del Milky River ridge fueron probablemente depositadas al inicio o a mediados del cron normal de Bruhnes (aproximadamente $780 \mathrm{ka}$ ) mientras que las tillitas inferiores del Milky River Ridge datan de una época anterior al periodo de Bruhnes, anterior al subcron normal de Olduvai $(1,98$ a 1,76 Ma) o bien al cron normal de Gauss (3,6 a 2,6 Ma). 


\section{INTRODUCTION}

Accurate identification of glacigenic deposits and interglacial markers such as paleosols is required in order to interpret past glacial and interglacial environments from sediments and paleosols. However, positive identification of old tills not associated with topographic features and very old paleosols can be problematic. Several authors have noted the resemblance between fan material (especially mudflow) and till (Blackwelder, 1928; Van Houten, 1957; Ryder, 1981). Likewise, pedologists have noted that interpretation of paleosols requires differentiation between features produced by pedogenic and geologic processes and that legitimate disagreements can arise regarding identification of paleosols (Yaalon, 1971; Birkeland, 1999).

These issues bear upon the reconstruction of preWisconsinan glacial/interglacial history of the Waterton-Glacier International Peace Park area of Alberta and Montana. Here, thick weathering zones, considered very strongly developed paleosols, cap pre-Illinoian diamictons of the Kennedy Drift (Alden, 1932) on a series of interfluves east of the Lewis Range. Most of these interfluves are remnants of the (Miocene-Pliocene) Flaxville, or number 1 bench, erosion surface (Alden, 1932; Fig. 1). Multiple, diamicton/paleosol units occur within the Kennedy Drift on several interfluves; the most complete sequences include five superposed diamicton/paleosol units at Mokowan Butte and Saint Mary Ridge (Karlstrom, 1988, 2000, Figs. 1 and 2). Although most workers have assumed that the Kennedy Drift is mostly till (Alden and Stebinger, 1913; Horberg, 1956; Richmond, 1957; Wagner, 1966; Karlstrom, 1987), others (Willis, 1902; Daly, 1912; Taylor, 1987; Little, 1998) suggest the material may consist mostly of mudflow and alluvial fan deposits. Similarly, whereas most have assumed that the strong weathering zones capping Kennedy drift units are paleosols (Horberg, 1956; Richmond, 1965; Karlstrom, 1988, 1991), Taylor (1987) asserts that the
FIGURE 1. Location of Cloudy Ridge and Milk River Ridge and other Flaxville surface remnants along the eastern margin of Waterton-Glacier parks.

Localisation du Cloudy Ridge et du Milk River Ridge et d'autres surfaces résiduelles le long de la marge orientale des parcs Waterton et Glacier.

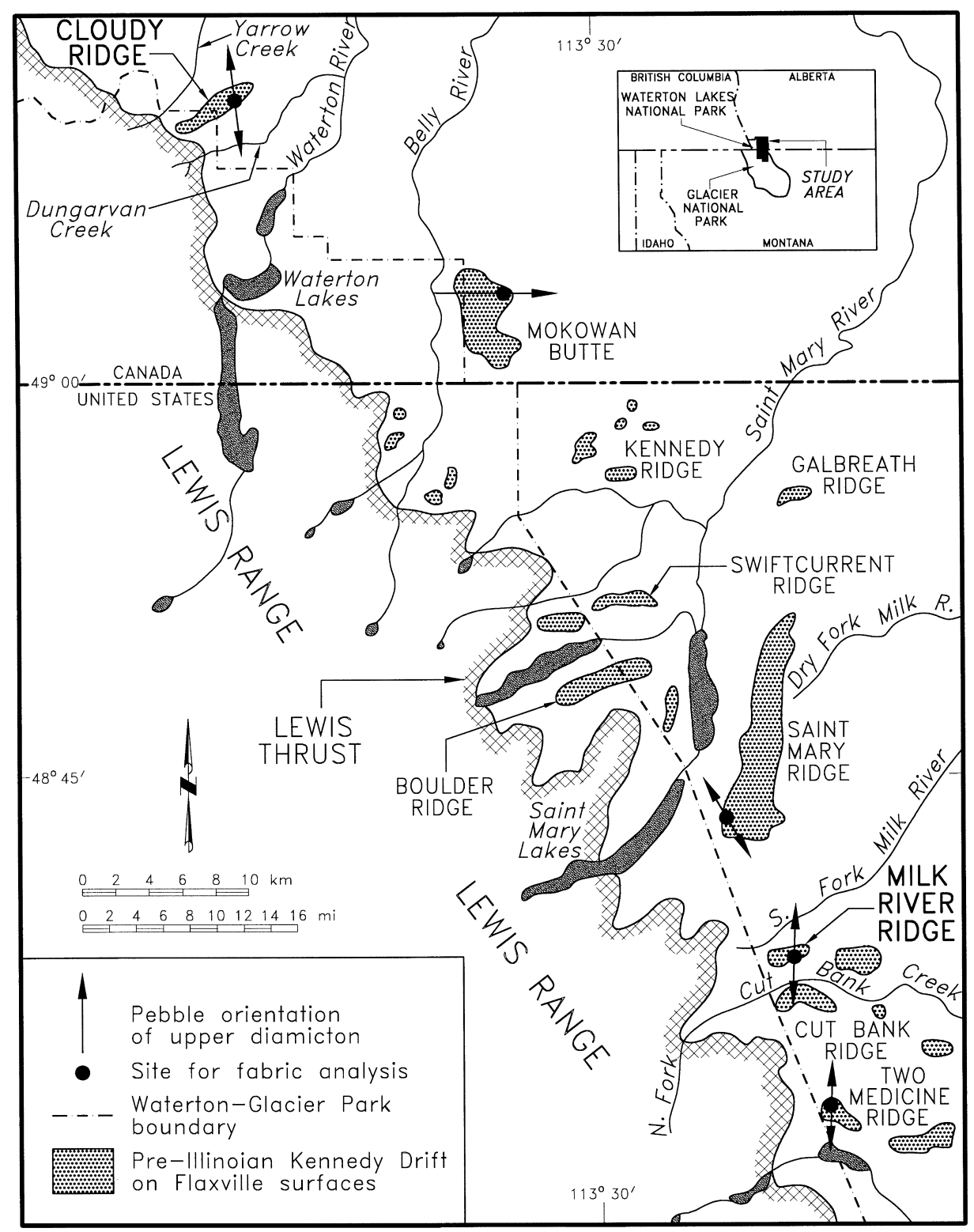


weathering zone capping the Cloudy Ridge diamicton is not a paleosol at all, but rather its features were mostly formed by post-burial diagenetic alterations.

Paleomagnetic analyses indicate the antiquity of the Kennedy Drift. At Saint Mary Ridge, the upper two diamic- ton/paleosol units have normal polarity whereas the lower three units are reversed (Cioppa et al.,1995; Figs. 1 and 2). On Mokowan Butte, the uppermost and lowest two diamicton/paleosol units are normally magnetized and two middle units have reversed polarity (Barendregt et al., 1991; Cioppa et al., 1995;

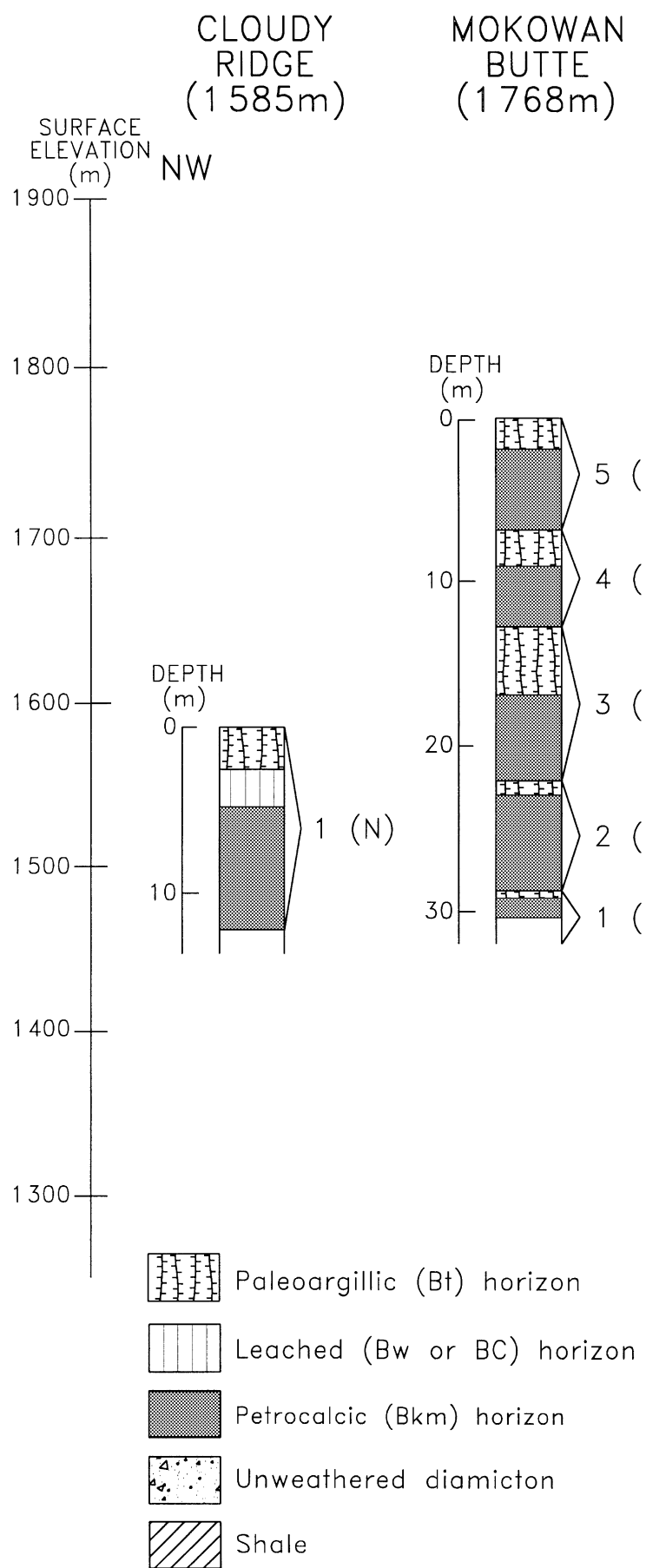

FIGURE 2. Stratigraphy and magnetic orientation of single (1) and multiple (1 through 5) diamicton/paleosol units within Kennedy Drift on Cloudy Ridge, Mokowan Butte, Saint Mary Ridge, Milk River Ridge, and Two Medicine Ridge. Vertical scale of sections is 10 times that of surface elevations. Polarity time scale from Shackelton et al. (1990).

\section{SAINT MARY MILK RIVER TWO MEDICINE RIDGE $(1804 m)$ RIDGE $(1847 \mathrm{~m})$ RIDGE}

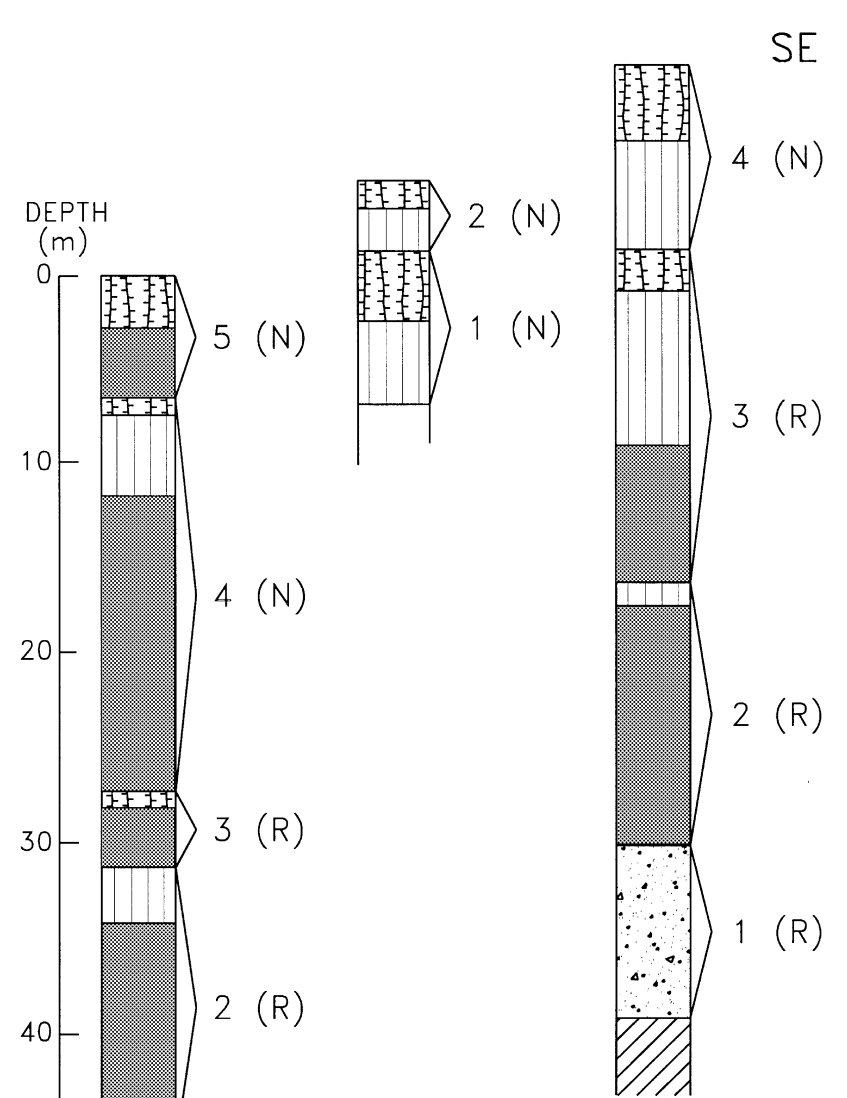

Polarity Time Scale

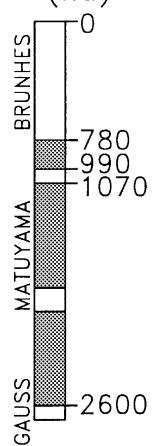

N Normal polarity

$R \quad$ Reverse polarity

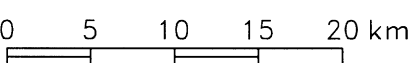

Stratigraphie et orientation magnétique d'unités simples ou multiples (1 à 5) de diamictons/paléosols faisant partie du Drift de Kennedy dans les Cloudy Ridge, Mokowan Butte, Saint Mary Ridge, Milk River Ridge et Two Medicine Ridge. L'échelle verticale représente 10 fois celle de l'altitude des surfaces. L'échelle polaire temporelle est de Shackelton et al. (1990). 
Fig. 2). Hence, the upper two units on Saint Mary Ridge and the upper unit on Mokowan Butte are thought to have been deposited during the Brunhes Normal Chron (0.78 Ma to present), the lower three units on Saint Mary Ridge and the middle two units on Mokowan Butte were deposited during the Matuyama Reversed Chron (2.6 to $0.78 \mathrm{Ma}$ ) and the lower two units on Mokowan Butte were probably deposited during the Gauss Normal Polarity Chron (3.6 to $2.6 \mathrm{Ma}$ ) or possibly the Olduvai (1.98-1.76 Ma) Normal Subchron (Cioppa et al., 1995).

With a few notable exceptions (Foscolos et al., 1977; Spooner et al., 1995; Barendregt et al., 1996; Jackson et al., 1996; Barendregt et al., 1998; Froese et al., 2000), early Pleistocene tills and palesols are rare in Canada and possibly nonexistant elsewhere in Alberta. Perhaps for this reason, Taylor (1987) interprets the Cloudy Ridge diamicton as probably a Tertiary or early Pleistocene fan (fluvial and mudflow) deposit. He also maintains that although the weathering zone which caps it is undoubtedly related to a landscape of the past, its "soil-like features" developed during and after burial of the diamicton. Little $(1995,1998)$ also considers the glacial origin of the Kennedy Drift on Mokowan Butte and Cloudy Ridge unproven. Therefore, we herein: 1) provide analyses of pebble fabrics and other sedimentological properties of diamicton/paleosol units on Cloudy Ridge (Alberta) and Milk River Ridge (Montana) in order to better assess their mode of deposition, 2) describe characteristics of the associated paleosols that pertain to their genesis, and 3) present new paleomagnetic data which help determine the antiquity of these units.

\section{CHARACTER OF KENNEDY DRIFT}

Observations at sites on nine Flaxville surface remnants (Karlstrom, 1988) indicate that unweathered Kennedy Drift is typically massive, homogeneous, matrix-supported, bouldery, sandy loam with weak to no bedding. Diamictons are 4- to over $10-\mathrm{m}$ thick, laterally continuous, and include a heterogeneous mix of Precambrian Belt (Purcell) Supergroup sedimentary rocks derived from the Rocky Mountains. Lithologies typically include about 65 to $75 \%$ red and green argillite, 20 to $30 \%$ limestone and dolomite, 5 to $10 \%$ quartzite, 0 to $5 \%$ sandstone, and 0 to $5 \%$ diorite and basalt. Clasts, generally subrounded, include boulders up to $3 \mathrm{~m}$ in diameter in some sections. Zones of predominantly rounded gravels and stones (probably water-washed), occur in some sections but are much less common than the massive, matrix-supported material. Striations are common on more resistant clasts, particularly the green argillites. Some stones have smooth, striated upper surfaces and irregular bottoms where they may have been plowed into the sediments. Stone pavements are rare but have been noted at two locales where they include bullet boulders and rocks with striated upper surfaces. Plucking features and beginnings of crescentic fractures and friction cracks are apparent on the upper surface of some clasts.

Diamictons are generally capped by thick weathering zones interpreted as strongly to very strongly developed paleosols (Karlstrom, 1988, 1991). Upper portions of diamicton/paleosol units are normally leached of primary carbonates whereas lower portions may be partly or completely carbonate-cemented. The extreme thickness $(1.5$ to $4+\mathrm{m})$ of paleoargillic hori- zons and their degree of weathering, clay buildup, rubification, and clay mineral alteration suggests considerable antiquity $\left(10^{5}\right.$ to $10^{6}$ years) for both the paleosols and associated diamictons (Karlstrom, 1988, 1991). Antiquity of diamicton/ paleosol units, also indicated by their height above modern stream level (122 to $580 \mathrm{~m}$ ), is confirmed by paleomagnetic data (Cioppa et al., 1995).

As noted, Taylor (1987) concludes that these weathering zones are not ancient soils. Although he acknowledges that the profile is "undoubtedly related to a landscape of the past, he postulates that the "soil-like features" (structure, redness, clay films, etc.) at Cloudy Ridge and the Cypress Hills in eastern Alberta were produced by diagenetic processes such as compaction, groundwater flow, recently precipitated hematite, etc., after the sediments were buried. However, the fact that relict paleosols occurring at the surface on Milk River Ridge and numerous other Flaxville surface remnants have virtually identical characteristics as these buried weathering zones (Karlstrom, 1988, 1991) invalidates this argument.

\section{SEDIMENTOLOGICAL PROPERTIES AND PEBBLE FABRIC ANALYSES}

\section{METHODS}

The diamicton/paleosol units of this study are exposed in a series of natural landslide scarps on Cloudy Ridge and Milk River Ridge (Fig. 1). Stratigraphic interpretation follows Karlstrom (1988; Fig. 2). Trenches previously excavated were re-opened in order to expose undisturbed material for pebble fabric analysis. Trend and plunge of the long axes of 50 pebbles were measured for each unit sampled. Prolate stones between about 1 and $50 \mathrm{~cm}$ in diameter were examined. Pebble orientations are plotted on 3-dimensional Schmidt equal-area nets using a computer program based on Kamb (1959) and traditional, 2-dimensional rose diagrams using $20^{\circ}$ intervals (Andrews, 1971).

Statistical evaluation of the fabric data is based on the eigenvalue method (Mark, 1973). Three mutually perpendicular axes (eigenvectors $\mathrm{V}_{1}, \mathrm{~V}_{2}$, and $\mathrm{V}_{3}$ ) are determined, the longest of which $\left(\mathrm{V}_{1}\right)$ lies in the direction of maximum pebble clustering. Orientation of the $\mathrm{V}_{1}$ eigenvector corresponds with mean lineation azimuth and plunge. Eigenvalues $\left(\mathrm{S}_{1}, \mathrm{~S}_{2}, \mathrm{~S}_{3}\right)$ measure the strength of clustering around each corresponding $\left(V_{1}, V_{2}, V_{3}\right)$ axis and eigenvalue $S_{3}$ is inversely proportional to the strength of the preferred plane of the fabric. Lawson (1979) and Dowdeswell et al. (1985) note that eigenvalues $\left(S_{1}\right.$ and $\left.S_{3}\right)$ provide a particularly useful means of describing and interpreting the genesis of diamictons.

\section{CRITERIA FOR IDENTIFICATION OF GLACIGENIC SEDIMENTS}

Various terms and classification systems have been applied to glacigenic sediments (Lawson, 1981; Dreimanis, 1989; Ham and Mickelson, 1994; Hart, 1994). Dowdeswell and Sharp (1986) distinguish four main types of sedimentary facies near modern terrestrial glaciers: basal melt-out till, deformed 
and undeformed lodgement till, sediment flows, and ice slope colluvium. They note that each facies has particular diagnostic properties, including pebble orientation (Figs. 3 and 4), eigenvalues, and other sedimentary properties. Melt-out till, deposited by melting of a glacier's stratified, clast-rich basal zone (Lawson, 1979, 1981), typically has a single mode of clast orientation and the degree of scattering around the direction of maximum clustering $\left(\mathrm{S}_{1}\right)$ is only slightly less than for pebbles in the basal zone of glacier ice.

Lodgement till is generally highly consolidated material deposited by accretion onto the bed from the sliding of an active glacier. Clasts are strongly oriented and commonly are rounded due to subglacial and post-depositional abrasion at the till surface. Boulder pavements may form when deposition of lodgement till is interrupted and erosion surfaces develop. Pavements may include bullet-shaped stones with striated upper surfaces and tapered ends pointing upglacier (Boulton, 1968) which are thought to be plowed into the till as ice flows over and around them (Hicock, 1991). Lodgement till fabrics show a slightly greater dispersion around the mean $\mathrm{V}_{1}$ axis than melt-out till (Dowdeswell et al., 1985). Whereas Mark (1973) asserts that a-b planes usually dip upglacier, Ham and Mickelson (1994) note that pebble imbrication in basal till may be oriented both up and down in the direction of glacier flow.
Lawson (1979) also asserts that pebble imbrication does not necessarily indicate the direction of glacier flow for the same reason.

A type of lodgement till deformed from pressures exerted from overriding ice is termed "deformation till" (Dreimanis, 1993) or "deformation lodgement till" (Dowdeswell and Sharp, 1986). Mechanisms thought to produce it include advancing freezing fronts, suitable subglacial conditions (Boulton and Dobbie, 1993), and the squeezing of previously deposited sediments directly by ice. Deformation lodgement till may exhibit shear zones or layering, folds, and dewatering structures such as diapirs and flame structures and commonly exhibit a "two layer" structure, including a structureless and friable upper layer (0-7 m) overlying a very compact diamicton with horizontal platy structure. High pore water pressure in the sediment may cause rotation of clasts within the sediment; hence, orientation and dip of pebbles is more dispersed in the upper friable zone than in the lower compact zone (Dowdeswell and Sharp, 1986). Pebble fabrics commonly display a-axes both transverse and parallel to ice movement and girdle-type distributions on Schmidt equal-area stereonets (Fig. 3).

Lawson (1981) notes that the primary process that deposits diamicton near the Matanuska Glacier terminus is sediment
FIGURE 3. Typical Schmidt equal area stereonet diagrams for different facies near modern terrestrial glaciers (after Dowdeswell and Sharp, 1986). Arrows indicate the observed direction of glacier or sediment flow. Diagrammes de projection équivalente de Schmidt de différents faciès à proximité de glaciers terrestres modernes (d'après Dowdeswell et Sharp, 1986). Les flèches donnent la direction observée de l'écoulement glaciaire ou de sédiments.
MELTOUT TILL

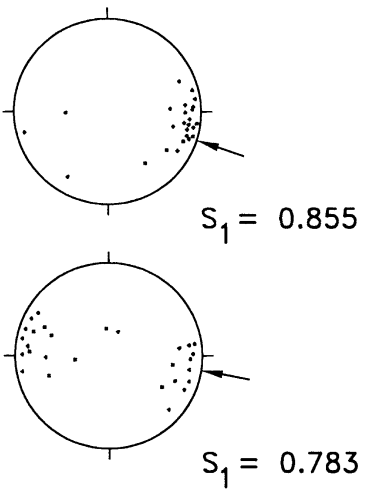

DEFORMED LODGEMENT TILL

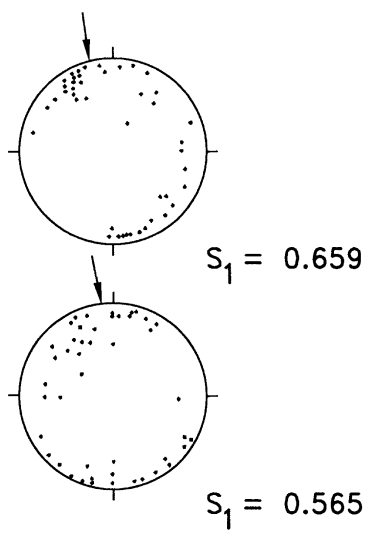

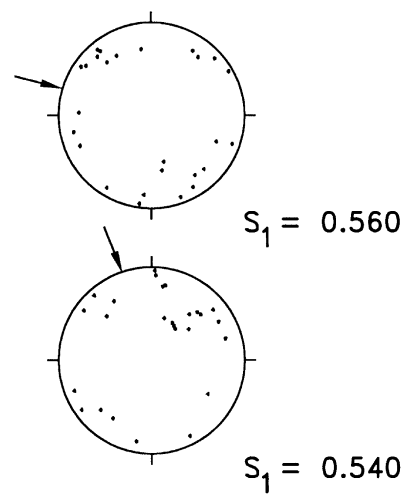

UNDEFORMED LODGEMENT TILL

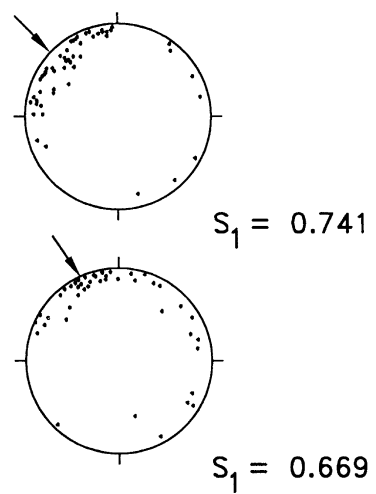

\section{SEDIMENT FLOWS}

$1=0.540$ 
FIGURE 4. Plot of $S_{1}$ and $S_{3}$ eigenvalues for diamict/paleosol units on Cloudy and Milk River ridges as compared to average values for meltout till, undeformed lodgement till, deformed lodgement till, glacigenic sediment flows (Dowdeswell and Sharp, 1986) and basal till (Ham and Mickelson, 1994).

Diagramme des valeurs propres $S_{1}$ et $S_{3}$ des unités de diamictons/ paléosols au Cloudy Ridge et au Milk River Ridge comparées aux valeurs moyennes du till de fusion, du till d'accrétion non déformé, du till d'accrétion déformé, des écoulements de sédiments glaciaires (Dowdeswell and Sharp, 1986), ainsi que du till de fond (Ham and Mickelson, 1994).

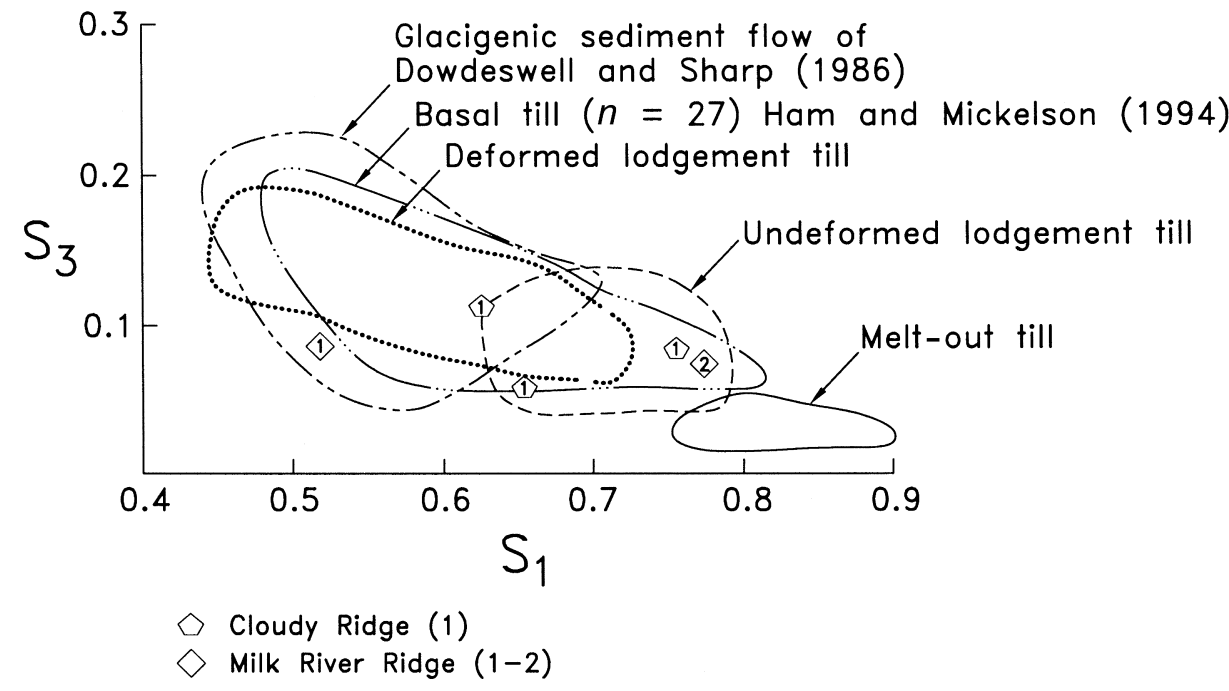

flow, or "the downslope transport of sediment-water mixtures under the force of gravity". Orientation of pebbles reflects the direction of sediment flow rather than the direction of ice movement. Dowdeswell et al. (1985) note that fabrics of these flows, which they term "glacigenic sediment flows", are typically weaker and more dispersed than those of melt-out or lodgement tills (Fig. 3). One or more axis of pebble orientation may lie transverse to the main direction (Mark, 1973). Finally, iceslope colluvium is produced by ablation along steep to overhanging slopes in active basal zone ice along the glacier terminus (Lawson, 1981). As in sediment flows, a poorly defined fabric commonly parallels the ice slope rather than the direction of glacier movement (Fig. 3). In contrast, Ham and Mickelson (1994) examined pebble fabrics of 27 samples near the Burroughs Glacier, Alaska, concluding that all are "basal tills" produced by progressive stagnation of debris-rich ice beneath a moving glacier during deglaciation.

Because fabric alone may not always be indicative of sediment genesis, most workers (Lawson, 1979; Dowdeswell and Sharp, 1986) suggest that it should be used in conjunction with other observations on sedimentological properties of materials. Lindsay (1968), for example, notes that, theoretically, mudflows could sometimes produce fabrics similar to tills. Additionally, Harris (1972) notes that after a sediment is deposited, its fabric may be modified by various agents, including the readvance of an ice sheet, ice pressing, soil creep, and frost action. Thus, Dowdeswell and Sharp (1986) suggest that an assemblage of characteristics, which may not all be present at any given site, be documented for identification of sediment as glacigenic. They conclude that relatively strong fabrics for melt-out and lodgement tills are more likely to be diagnostic than weaker fabrics.

\section{MILK RIVER RIDGE DIAMICTONS}

Milk River Ridge is a relatively narrow, flat, west-east-trending interfluve considered a remnant of the Flaxville bench (Alden, 1932). A trench excavated on the southern flank of Milk River Ridge (NE1/4, SW1/4 Sec. 8, T33N., R13W.; UTM
53887 N., 3278 E.; Fox Creek 7.5 minute Quadrangle, USA) exposes two superposed diamicton/paleosol units within Kennedy Drift that are distinguished on the basis of the intercalated paleosol and the fact that clasts are considerably more weathered in the lower unit (Figs. 1, 2 and 5). Here, the interfluve stands about $323 \mathrm{~m}$ above the level of the North Fork of the Cut Bank Creek to the south and $183 \mathrm{~m}$ above the level of the North Fork of the Milk River to the north. As is typical of Kennedy Drift, both diamictons are massive, with weak to no bedding, and have considerable thickness (about 4 and $8+\mathrm{m}$ ) and horizontal extent. They include numerous lithologies of Precambrian Belt (Purcell) Supergroup sedimentary rocks, with about 71 to $86 \%$ red and green argillite, 6 to $20 \%$ quartzite, 0 to $10 \%$ sandstone, and 0 to $1 \%$ diorite or basalt. Texture of relatively unweathered diamicton is stony to very stony sandy loam, with approximately 46 to $48 \%$ fines, whereas paleoargillic horizons have about 59 to $70 \%$ fine-grained sediments. Clasts are subrounded and up to $60 \mathrm{~cm}$ in diameter. Both units are entirely leached of carbonates.

Both diamictons have sedimentological properties suggestive of undeformed lodgement till. The matrix is relatively compact. Striations on upper surfaces of some green argillite clasts are oriented (S-N) into the hill. Some stones have smooth, striated upper surfaces, sometimes exhibiting nailhead striae, and irregular bottom surfaces. Multiple stoss-lee features occur on some clasts, probably indicating numerous stoss-lee erosion cycles (Sharp, 1982). Plucking features, and the beginnings of crescentic fractures and friction cracks are evident on the upper surfaces of some clasts. Plucking features show at least two cycles. Fissility, which can develop as a result of glacier unloading (Doweswell and Sharp, 1986), was also observed within the sediment. Finally, there is a suggestion of a stone pavement in the lower unit. The contact between the upper and lower diamictons is not well defined except by soil color and texture changes and the fact that the lower unit has many more strongly weathered clasts than the upper unit.

The Schmidt equal-area net and rose diagram indicate the upper diamicton/paleosol unit has a strong unimodal S-N 
FIGURE 5. Stratigraphy and paleomagnetism of two superposed diamict/paleosol units on Milk River Ridge. Pebble fabric data are represented by Schmidt equal-area nets and wind rose diagrams.

Stratigraphie et paléomagnétisme de deux unités superposées de diamictons/paléosols au Milk River Ridge. L'orientation des cailloux est donnée par les projections équivalentes de Schmidt et les diagrammes circulaires.

\section{MILK RIVER RIDGE PEBBLE FABRICS}

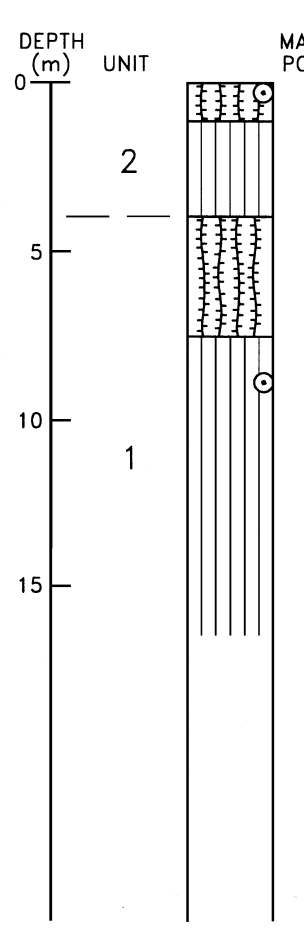

Upper Diamicton

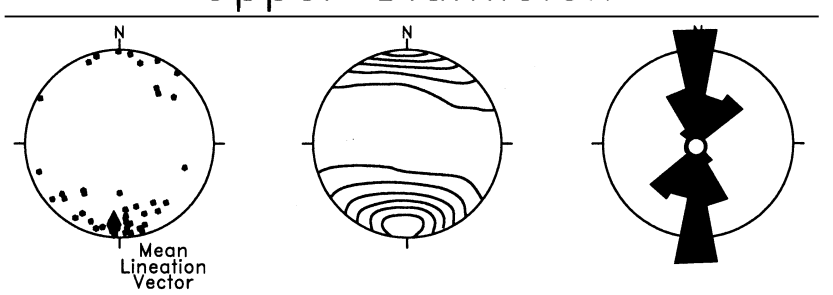

N

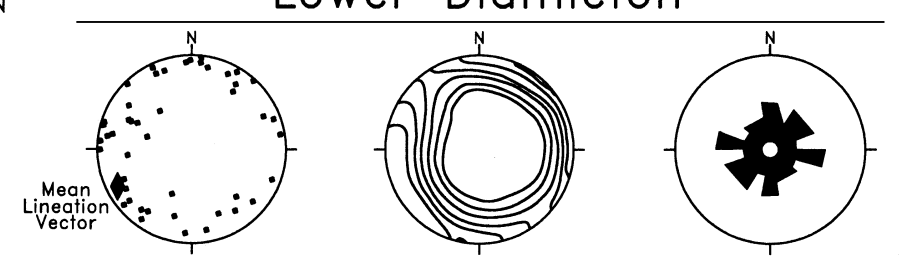

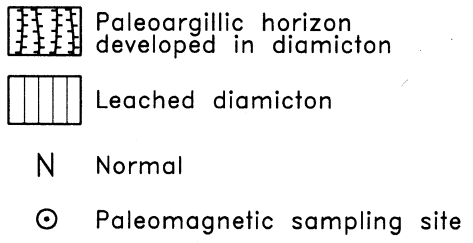

fabric (Fig. 5). $S_{1}$ and $S_{3}$ values (0.772 and 0.064 ) are typical for undeformed lodgement till or possibly melt-out till. The Schmidt stereonet most closely resembles the pattern typical of undeformed lodgement till (Figs. 3 and 4). Measured pebble dip, averaging 14 to 16 degrees to the south, southwest and southeast, suggests, but does not prove, that the diamicton was deposited by a glacier flowing from south to north, transverse to the trend of modern drainages (Fig. 1). This ice direction would follow the northward regional slope (up to $5.5 \mathrm{~m} / \mathrm{km}$ ) of the Flaxville surface remants east of Glacier National Park (Fig. 2). However, because pebble imbrication may be in either up- or down-glacier directions, flow also could have been southward.

Fabric of the lower diamicton is less well defined. There is a predominantly WSW-ENE trend but the degree of scattering around mean direction of pebble orientation is much greater (Fig. 5). The girdle pattern of the Schmidt equal-area net is more characteristic of deformed lodgement till or glacigenic sediment flows than undeformed lodgement till. $S_{1}$ and $S_{3}$ values ( 0.502 and 0.083 , respectively) fall within the range of glacigenic sediment flows (Fig. 4). However, the mean lineation plunge of pebbles $\left(\mathrm{V}_{1} ; 11^{\circ}\right.$ to the $\left.\mathrm{SW}\right)$ indicates the kind of imbrication typical of lodgement till. And mean pebble $\operatorname{dip}\left(15^{\circ}\right)$ is closer to the norm for deformed lodgement till $\left(17^{\circ}\right)$ than glacigenic sediment flow $\left(20^{\circ}\right.$; Johnson, 1990). Hence, although fabric of the lower unit is weaker than that of the other units examined, based on the suite of sedimentological characteristics observed (striated stones, compact matrix, weak stone pavement, etc.), it is most probably either deformed lodgement till and/or was originally deposited as undeformed lodgement till and its fabric was later altered dur- ing the emplacement of the overlying till. Owing to the lack of sedimentary features typical of deformation till such as shear zones, folding, diapirs, etc., the latter interpretation seems more likely.

\section{CLOUDY RIDGE DIAMICTON}

The surface here referred to as Cloudy Ridge is a gentlysloping (10\%), northeast-trending, approximately 3-km-long interfluve at the base of the mountain front, which straddles the northeastern corner of Waterton Park, Alberta (Figs. 1 and 2). Horberg (1954) considered this surface a possible remnant of Alden's (1932) Number 2 bench (early Pleistocene; Figs. 1 and 2). The interfluve stands about $122 \mathrm{~m}$ above the level of Dungarvan Creek to the south and Yarrow Creek to the north. A series of lateral moraines mantling the northern portion of the interfluve were probably deposited by alpine glacier ice from the north during the last glaciation. Also, during the last glaciation, granitic erratics of Laurentide provenance were deposited on the eastern part of Cloudy Ridge to an elevation of $1585 \mathrm{~m}$. These erratics have been dated (Jackson et al., 1999) by the cosmogenic Chlorine ${ }^{36}$ method, yielding a Late Wisconsinan age (about $15 \mathrm{ka}$ ). Wagner (1966) examined sediments exposed beneath the surface of Cloudy Ridge and concluded they are tills deposited during two Cordilleran glaciations (Illinoian? and Late Wisconsinan ). Likewise, Stalker and Harrison (1977) conclude that the older material is till that probably dates back to the early Illinoian glaciation. Perhaps because this interfluve directly abuts the mountain front and slopes approximately $10 \%$ to the northeast, Taylor (1987) argues that it is underlain mostly by Tertiary or early 
Pleistocene colluvium. He concludes that the sediment exposed here is not glacigenic and the weathering zone is not pedogenic.

A $20 \mathrm{~m}$, vertical trench excavated on the southeastern flank of the interfluve (54548 N., 722 E., Waterton Lakes, $82 \mathrm{H} / 4$, Canada) about $2.2 \mathrm{~km} \mathrm{NNE}$ of the mountain front exposes a diamicton similar to the Kennedy Drift on Flaxville surfaces to the south. The upper $80 \mathrm{~cm}$ of the section consists of a brown, cumulic A horizon developed in angular, gravelly material of local origin with a primarily downslope orientation, interpreted as colluvium (Karlstrom, 1981). Underlying the colluvium is approximately $19 \mathrm{~m}$ of diamicton capped by a thick, strongly oxidized paleosol. The diamicton is massive, generally unstratified, and includes about 35 to $50 \%$ rounded and subangular gravels with stones up to $1+\mathrm{m}$ in diameter, including a majority of allochthanous red and green argillite and some basalt clasts. Whereas the upper approximately $3.5 \mathrm{~m}$ of the diamicton/paleosol are leached of primary carbonates, the lower approximately $15 \mathrm{~m}$ is cemented by reprecipitated carbonates. Percentage of coarse fragments increases to about $75 \%$ in the lowest, carbonate-cemented portions of the section where the material appears more alluvial or glacio-fluvial in origin.

Striations, bullet boulders, and faceted stones occur throughout the section. A weak stone pavement near the base of the unit includes bullet boulders and striations on the upper surfaces of the rocks. Fissility evident within the upper paleosol could represent either the effects of glacier unloading
(Dowdeswell and Sharp, 1986) or periglacial processes (Van Vliet and Langhor, 1984).

Pebbles sampled from the upper meter of the paleosol show a strong south-north orientation (Fig. 6). $S_{1}$ and $S_{3}$ values ( 0.757 and 0.070 , respectively) and the Schmidt equal-area net are typical of undeformed lodgement till or basal till deposited as ground moraine (Figs. 3, 4, and 6). Pebbles dip an average of $14^{\circ}$ mostly toward the south and southeast. Pebbles sampled from the calcrete at depths of 8 to $15 \mathrm{~m}$ are also oriented S-N with imbrication toward the southeast and south. This fabric shows slightly less clustering around the mean direction $\left(V_{1}\right) . S_{1}$ and $S_{3}$ values $(0.618$ and 0.111 , respectively) of pebbles at this depth fall within the range of values typical of undeformed and deformed lodgement till and/or glacigenic sediment flows (Figs. 4 and 6). The Schmidt equal area net, however, most resembles those typical of undeformed or deformed lodgement till (Figs. 2 and 6). Average pebble dip $\left(17^{\circ}\right)$ is typical of deformed lodgement till. A third fabric sample taken for the entire section is also indicative of undeformed lodgement or basal till (Ham and Mickelson, 1994), with $S_{1}$ and $\mathrm{S}_{3}$ values of 0.655 and 0.060 , respectively. Mean pebble dip $13^{\circ}$, predominantly toward the $S$ and $S W$ ) and azimuth of this sample suggest glacier flow was either from south to north or from north to south. These data suggest that the diamicton on Cloudy Ridge represents one undeformed lodgement or basal till deposited by glacier ice flowing either northward or southward along the mountain front.
FIGURE 6. Stratigraphy, magnetic orientation, and pebble fabric data for diamict/paleosol unit on Cloudy Ridge. The upper fabric was obtained from pebbles in the upper $m$ of the paleoargillic horizon and lower fabric was taken from calcrete 8 to $15 \mathrm{~m}$ depth.

Stratigraphie, orientation magnétique et orientation des cailloux de l'unité de diamicton/paléosol au Cloudy Ridge. Les données de la partie supérieure ont été obtenues à partir des cailloux du premier mètre de l'horizon paléoargilique et les données de la partie inférieure proviennent de cailloux prélevés dans les encroûtements calcaires situés de 8 à $15 \mathrm{~m}$ de profondeur.

\section{CLOUDY RIDGE PEBBLE FABRICS}

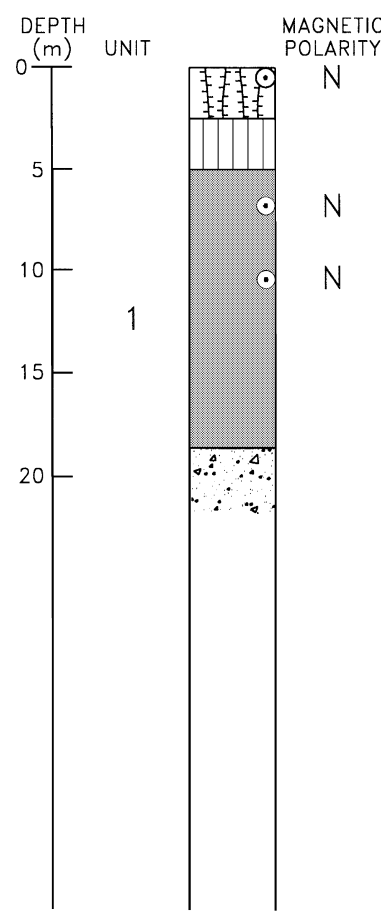

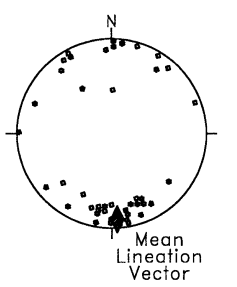
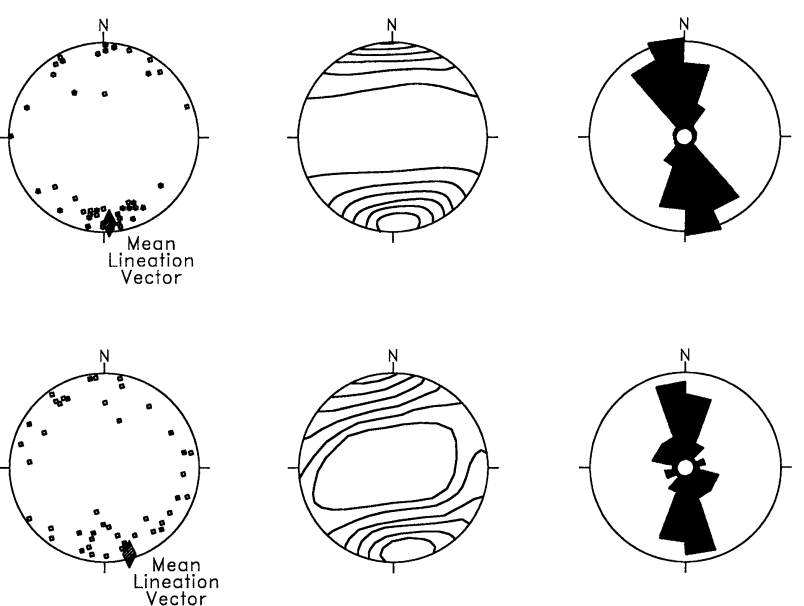

F= $=$ Paleogrgillic horizon developed in diamicton

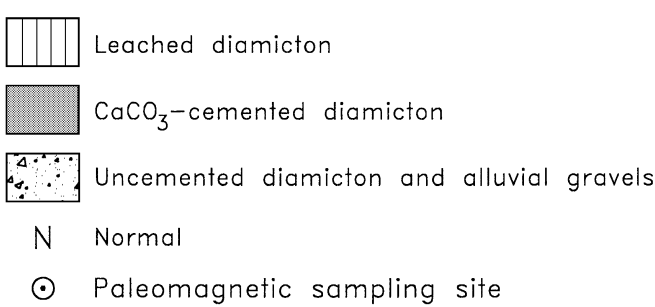

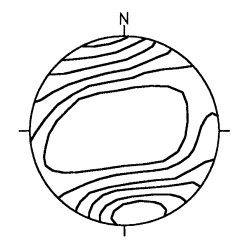




\section{FABRIC AND ORIGIN OF DIAMICTONS}

Fabric and sedimentological properties of Kennedy Drift diamictons on Milk River Ridge, Cloudy Ridge, and other interfluves east of Waterton-Glacier National Parks (Karlstrom, 2000) exhibit many similarities. All are poorly sorted, non-stratified to weakly stratified, have a wide range of clast lithologies and sizes, and commonly include striated clasts and/or bullet boulders. Some locally exhibit weak fissility, boulder pavements, and a compact structure typical of undeformed lodgement till. Most diamictons are capped by paleosols of varying thickness which are weathered to various degrees. Typically, there is an abrupt, smooth boundary between each paleosol and the overlying diamicton.

On each interfluve examined, the uppermost diamictons have a strong fabric $\left(S_{1}\right.$ values greater than 0.650 and $S_{3}$ values less than 0.110 ) with a unimodal pebble orientation and pebble dip angles averaging 14 to $16^{\circ}$. These characteristics are typical of undeformed lodgement till (Dowdeswell and Sharp, 1986) or basal till (Ham and Mickelson, 1994). The mode of pebble orientation $\left(\mathrm{V}_{1}\right)$ and imbrication within the upper diamicton on Milk River Ridge suggest that it was deposited by a glacier flowing from south to north or north to south across the interfluve at right angles to adjacent modern drainages (Fig. 1). This pattern suggests that either the associated glacier filled a shallower version of the drainage and spread laterally across the interfluve or that the interfluve then comprised a drainage bottom and subsequent reversal of topography has occurred. In this latter scenario, the drainage courses followed by these glaciers would be mostly nonexistent today.

The mode of pebble orientation $\left(\mathrm{V}_{1}\right)$ and angle of pebble dip of the diamicton at Cloudy Ridge suggests it was deposited by a glacier flowing southward along the mountain front or by a piedmont glacier from the Waterton Valley that flowed northward along the mountain front.

The fabric of the lower diamicton/paleosol unit on Milk River Ridge is less well defined than the others, perhaps because it was altered during emplacement of the upper diamicton. The fabric falls within the range of glacigenic sediment flow (Fig. 4) but many of the diamicton's sedimentary properties, including striated stones, fissility, and a weak stone pavement, suggest that it is deformed lodgement or basal till. Direction of pebble orientation and plunge suggests this diamicton was also deposited by ice flowing northward or southward parallel to the mountain front.

Thus, numerous properties of the diamictons indicate a primarily glacigenic rather than colluvial or alluvial fan origin. These include pebble fabrics, sedimentological characteristics such as striated stones and boulder pavements, and the wide variety of lithologies and clast sizes present. Colluvial (including mudflow) deposits, by contrast, could be expected to have less compact matrices, more homogeneous lithologies, and more angular clasts with long axes oriented in the downslope direction, whereas alluvium deposited on fan surfaces would be expected to exhibit greater sorting and rounding of clasts and less compact matrices than these diamictons. And although the Cloudy Ridge diamicton/paleosol caps a gently sloping fan-like surface which directly abuts the mountain front, Milk River Ridge and numerous other Flaxville surface remnants lie 2.2 to $10 \mathrm{~km}$ east of the nearest mountain (Karlstrom 1988, 1991). Finally, the diamicton/paleosol units capping the Flaxville remnants appear to have a distinctly horizontal aspect, as would be expected of material deposited subglacially, in contrast to sediment deposited by water and gravity on alluvial fan surfaces, which would slope toward the plains.

\section{ANALYSIS OF PALEOSOLS}

\section{METHODS}

Paleosol horizons were described and sampled according to the procedures of the Soil Survey Staff (1975) and Guthrie and Witty (1982). Samples were analyzed to determine particle size (Piper, 1950) using U.S. Department of Agriculture size limits, organic matter composition (Sims and Haby, 1971), and percent calcium carbonate and dolomite (Dreimanis, 1962). Percentages of free iron, aluminum, and manganese were determined for selected samples using the dithionite-citrate-bicarbonate method (Mehra and Jackson, 1960). Pebble lithologies were identified for selected horizons in order to determine parent material composition and degree of clast weathering was noted in order to assess relative age. Clay minerals were identified by X-ray diffraction (Millot, 1970). Selected samples were analyzed in greater detail in order to better identify mixed-layer clays using procedures of $A$. E. Foscolos (1980, personal communication; Foscolos et al., 1977).

Relative development of the paleosols is compared with modern soils using profile-development (Harden, 1982) and clay-accumulation indices (Levine and Ciolkosz, 1983). Classification of paleosols can be problematic due to the possibility of post-burial diagenetic alterations. However, this does not seem to be a problem in this study because relict (surface) paleosols closely resemble those that have been buried. The U.S. Comprehensive Soil Classification System (Soil Survey Staff, 1975) is used here rather than the Canadian System of Soil Classification (Canada Soil Survey Committee, 1978) because the paleosols better resemble soils formed in warmer, more equable climates than soils typically found in Canada.

\section{PALEOSOLS AT MILK RIVER AND CLOUDY RIDGES}

The two superposed diamictons at Milk River Ridge are each capped by thick weathering zones interpreted as very strongly developed paleosols. Primary carbonates and carbonate rocks have been entirely leached and removed from both paleosols. The paleoargillic (Bt) horizon of the upper paleosol is a $135-\mathrm{cm}$ thick stony loam (30\% stones), which includes 24 to $26 \%$ clay, or $13 \%$ more clay than the underlying Bw horizon, and clay films on ped faces and some clasts (Table I). It is slightly acidic, with $\mathrm{pH}$ values ranging from 6.3 to 6.9. Rubification in the Bt horizon to yellowish red (5YR 5/8 moist) and strong brown (7.5YR 5/6 moist) colors coincides 
TABLE I

Summary of laboratory data for paleosols on Milk River Ridge and Cloudy Ridge and a representative local modern (post-Wisconsinan) soil

\begin{tabular}{|c|c|c|c|c|c|c|c|c|c|c|c|}
\hline & & & $\begin{array}{l}\text { a } \\
\text { ticle s }\end{array}$ & & & b & & c & & & e \\
\hline Horizon & $\begin{array}{l}\text { Depth } \\
(\mathrm{cm})\end{array}$ & $\begin{array}{c}\% \\
\text { sand }\end{array}$ & $\begin{array}{l}\% \\
\text { silt }\end{array}$ & $\begin{array}{c}\% \\
\text { clay }\end{array}$ & $\mathrm{pH}$ & $\begin{array}{c}\% \\
\text { O.M. }\end{array}$ & $\begin{array}{c}\% \\
\mathrm{CaCo}_{3}\end{array}$ & $\begin{array}{c}\% \\
\text { Dolo }\end{array}$ & $\begin{array}{l}\% \\
\mathrm{Fe}\end{array}$ & $\begin{array}{c}\text { free } \\
\mathrm{Al}\end{array}$ & $\begin{array}{c}\text { Clay } \\
\text { Minerals }\end{array}$ \\
\hline
\end{tabular}

\section{MILK RIVER RIDGE PALEOSOLS}

Upper paleosol: Typic Paleudalf (Soil Survey Staff, 1975); $\mathrm{HPI}^{\dagger}=149 ; \mathrm{CAI}^{\mathrm{g}}=2110$

\begin{tabular}{|c|c|c|c|c|c|c|c|c|c|c|}
\hline $0-10$ & 52 & 27 & 21 & 6.2 & 1.2 & 0.0 & 0.0 & 0.92 & 0.18 & $2 \mathrm{I}, 2 \mathrm{~S}, 1 \mathrm{~K}, \mathrm{TC}$ \\
\hline $10-70$ & 49 & 25 & 26 & 6.3 & 1.0 & 0.0 & 0.0 & & & \\
\hline $70-95$ & 42 & 34 & 24 & 6.3 & 0.0 & 0.0 & 0.0 & & & \\
\hline $95-145$ & 40 & 34 & 26 & 6.9 & 0,1 & 0,0 & 0.0 & 1.98 & 0.30 & $3 \mathrm{I}, 2 \mathrm{H}-\mathrm{I}, 1 \mathrm{~K}$ \\
\hline $145-211$ & 65 & 23 & 12 & 6.3 & 0.2 & 0.0 & 0.0 & & & \\
\hline $211-236$ & 58 & 31 & 11 & 6.2 & 0.5 & 0.0 & 0.0 & & & 3I, 2H-I, 1K \\
\hline $236-311$ & 72 & 18 & 10 & 6.5 & 0.0 & 0.0 & 0.0 & & & \\
\hline $311-387$ & 67 & 17 & 16 & 6.3 & 0.1 & 0.0 & 0.0 & 1.74 & 0.34 & $3 \mathrm{I}, 2 \mathrm{H}-\mathrm{I}, 1 \mathrm{~K}, 1 \mathrm{C}$ \\
\hline
\end{tabular}

Lower paleosol: Typic Paleudalf; $\mathrm{HPI}=228.9 ; \mathrm{CAl}=5420$

\begin{tabular}{|c|c|c|c|c|c|c|c|c|c|c|c|}
\hline Btb1 & $387-493$ & 54 & 20 & 26 & 6.1 & - & 0.0 & 0.0 & & & \\
\hline Btb2 & $493-582$ & 60 & 16 & 24 & 6.1 & - & 0.0 & 0.0 & 1.92 & 0.46 & $3 \mathrm{I}, 2 \mathrm{H}-\mathrm{I}, 1 \mathrm{~K}$ \\
\hline Btb3 & $582-659$ & 50 & 30 & 20 & 6.5 & - & 0.0 & 0.0 & & & \\
\hline Btb4 & $659-756$ & 58 & 22 & 20 & 6.3 & - & 0,0 & 0.0 & & & $3 \mathrm{I}, 2 \mathrm{H}-\mathrm{I}, 1 \mathrm{~K}$ \\
\hline Bwb1 & $756-951$ & 57 & 33 & 10 & 6.4 & - & 0.0 & 0.0 & & & \\
\hline Bwb2 & $951-1135$ & 66 & 29 & 5 & 6.5 & - & 0.0 & 0.0 & 1.48 & 0.30 & $3 \mathrm{I}, 2 \mathrm{H}-\mathrm{I}, 1 \mathrm{~K}, \mathrm{TC}, \mathrm{TC}-\mathrm{V}$ \\
\hline $\mathrm{Cb}$ & $1135-1192$ & 75 & 17 & 8 & 6.2 & - & 0.0 & 0.0 & & & $3 \mathrm{I}, 1 \mathrm{~K}, 2 \mathrm{C}$ \\
\hline
\end{tabular}

CLOUDY RIDGE PALEOSOL: Typic Paleudalf; HPI = 69; CAI = 2192

\begin{tabular}{|c|c|c|c|c|c|c|c|c|c|}
\hline A1 & $0-31$ & 54 & 34 & 12 & 8.0 & 2.5 & 24.0 & 2.0 & $3 \mathrm{I}, 2 \mathrm{~K}, 2 \mathrm{C}$ \\
\hline A3 & $31-53$ & 54 & 32 & 14 & 8.1 & 1.9 & 19.0 & 2.0 & \\
\hline $2 \mathrm{ABb}$ & $53-78$ & 60 & 26 & 14 & 8.5 & 0.3 & 0.0 & 0.0 & \\
\hline 2Btb1 & 78-109 & 40 & 34 & 26 & 7.8 & 1.2 & 0.0 & 0.0 & \\
\hline 2Btb2 & 109-195 & 30 & 48 & 22 & 8.2 & 0.2 & 0.0 & 0.0 & $2 \mathrm{I}, 2 \mathrm{C}, 2 \mathrm{C}-\mathrm{V}, 1 \mathrm{~K}, \mathrm{TH}-$ \\
\hline 2Btb3 & $195-261$ & 48 & 38 & 14 & 8.3 & 0.5 & 0.0 & 0.0 & \\
\hline 2Bwb1 & $261-307$ & 46 & 46 & 8 & 8.0 & 0.3 & 0.0 & 0.0 & \\
\hline 2Bwb2 & $307-353$ & 50 & 38 & 12 & 8.1 & - & 0.0 & 0.0 & $2 \mathrm{I}, 21 \mathrm{~K}, 1 \mathrm{C}, 1 \mathrm{C}-\mathrm{V}$ \\
\hline \multicolumn{10}{|c|}{ MODERN (POST-WISCONSINAN) SOIL: Typic Cryochrept; HPI = 10.40; CAI = 0} \\
\hline A & $0-6$ & 53 & 39 & 8 & 6.9 & 5.8 & 0.0 & 0.0 & $2 \mathrm{I}, 2 \mathrm{~K}, 1 \mathrm{C}, 1 \mathrm{~V}, 1 \mathrm{I}-\mathrm{C}$ \\
\hline $\mathrm{E}$ & $6-14$ & 22 & 61 & 17 & 7.3 & 3.7 & 0.0 & 0.0 & \\
\hline Bw & $14-27$ & 30 & 47 & 23 & 7.5 & 2.8 & 5.7 & 2.5 & \\
\hline Bk1 & $27-64$ & 32 & 45 & 23 & 7.5 & 2.6 & 14.0 & 5.5 & $3 \mathrm{I}, 2 \mathrm{~K}, 2 \mathrm{C}, 1 \mathrm{~V}, 1 \mathrm{I}-\mathrm{C}$ \\
\hline C & 64-144+ & 33 & 44 & 23 & 8.1 & 0.6 & 21.0 & 5.4 & 3I, 2K, 2C, $1 \mathrm{~V}$ \\
\hline
\end{tabular}

a- using U.S. Department of Agriculture size limits

b- organic matter

c- dolomite

d- dithionite-citrate-bicarbonate extractable free iron (Fe) and aluminum ( $\mathrm{Al}$ ) of fine earth fraction

e- I=illite, $\mathrm{K}=$ kaolinite, $\mathrm{C}=$ chlorite, $\mathrm{V}=$ vermiculite; $3=$ dominant, $2=$ moderate, $1=$ minor, $\mathrm{T}=$ trace quantities

f- HPI = Harden profile index (Harden, 1982)

g- $\mathrm{CAl}=$ clay accumulation index (Levine and Ciolkosz, 1983) 
with relatively high concentrations $(1.98 \%)$ of dithioniteextractable free iron and a relatively high percentage (48) of weathered clasts and "ghost stones". The underlying $242-\mathrm{cm}$ thick, cambic $(\mathrm{Bw})$ horizon is slightly less oxidized and has lower concentrations of clay (10 to $16 \%$ ), free iron (1.47\%), and weathered clasts (23\%). All horizons have moderate to strong granular to subangular blocky structure.

The paleoargillic horizon of the lower paleosol is similar to that of the upper paleosol but is thicker ( $369 \mathrm{~cm}$ thick) and more weathered. It is a yellowish red to strong brown stony loam with 20 to $26 \%$ clay, or $18 \%$ more clay than the underlying $\mathrm{C}$ horizon, and thick clay films on ped faces and some clasts (Table I). It is slightly more acid ( $\mathrm{pH}$ is 6.1 to 6.5 ) than the overlying paleosol and includes $1.92 \%$ free iron, $0.46 \%$ free aluminum, and $56 \%$ weathered clasts and ghost stones. Again, horizons have granular to sub-angular blocky structure. The yellowish brown (10YR 5/4 moist) C horizon comes closest to representing unweathered till in this section. This horizon includes 5 to $10 \%$ clay, $1.48 \%$ free iron, $0.30 \%$ free aluminum, only $11 \%$ weathered clasts, and no (single grain) structure.

Clay mineralogy of relatively unweathered diamicton (C horizon of the lower paleosol) includes illite, chlorite, and kaolinite directly inherited from parent materials (Table I, Fig. 7). Paleoargillic (Bt) horizons of both paleosols, by contrast, are characterized by the weathering and loss of inherited chlorite and the occurrence of a mixed-layer clay mineral, tentatively identified as kaolinite-illite or halloysite-illite, which forms a broad hump between 8 and $9 \AA$. This mineral is characteristic of most paleosols developed in Kennedy Drift (Karlstrom, $1981,1988)$. In addition, trace amounts of chlorite-vermiculite occur in the Btb1 horizon of the lower paleosol (Table II).

The weathering profile capping the Cloudy Ridge diamicton includes an $86 \mathrm{~cm}$, brown ABb horizon, a 183-cm thick, yellowish red (5YR 4/6 moist) paleoargillic (Bt) horizon, and a 92-cm thick, leached, brown (7.4YR 4/4 moist) Bw horizon, overlying about $15 \mathrm{~m}$ of carbonate-cemented diamicton and

TABLE II

Summary of magnetizations

\begin{tabular}{|c|c|c|c|c|c|c|}
\hline Site & Polarity & $n$ & $\begin{array}{l}\mathrm{D} \\
\left({ }^{\circ}\right)\end{array}$ & $\begin{array}{l}1 \\
\left({ }^{\circ}\right)\end{array}$ & $k$ & $\partial_{95}$ \\
\hline \multicolumn{7}{|l|}{ Milk River Ridge } \\
\hline $\begin{array}{l}\text { Upper paleosol / } \\
\text { diamicton (Unit 2) }\end{array}$ & $\mathrm{N}$ & 15 & 350 & 62 & 35 & 7 \\
\hline $\begin{array}{l}\text { Lower paleosol / } \\
\text { diamicton (Unit 1) }\end{array}$ & $\mathrm{N}$ & 10 & 169 & 52 & 10 & 16 \\
\hline \multicolumn{7}{|l|}{ Cloudy Ridge } \\
\hline $\begin{array}{l}\text { Upper paleosol / } \\
\text { diamicton (Unit 1) }\end{array}$ & $\mathrm{N}$ & 16 & 357 & 41 & 8 & 14 \\
\hline $\begin{array}{l}\text { Lower paleosol / } \\
\text { diamicton (Unit 1) }\end{array}$ & $\mathrm{N}$ & 8 & 360 & 66 & 21 & 12 \\
\hline
\end{tabular}

$\mathrm{D}=$ declination $\mathrm{I} \mathrm{I}=$ inclination $; \mathrm{k}=$ precision parameter $; \partial_{95}=$ circle of confidence $(P=0.05)$ outwash or alluvium (Table II). The upper $3.5 \mathrm{~m}$ of the paleosol is entirely leached of carbonates. The paleoargillic horizon is enriched in illuvial clay and includes up to $26 \%$ clay, or $16 \%$ more than the underlying Bw horizons (Table I). Bt horizons include moderate to thick clay films on ped faces and pebble surfaces. The Bt horizon includes only 15 to $20 \%$ rounded clasts, many of which are highly weathered and/or "ghosts". Clay minerals include mixed-layer kaolinite-illite and chloritevermiculite in addition to inherited kaolinite, illite, and chlorite. Mixed-layer clays are most abundant in the paleoargillic horizon (Table I; Fig. 8). Chlorite-vermiculite commonly forms under alternating wet and dry soil forming conditions (Jackson, 1965) and/or results from partial interlayering of hydroxy aluminum or hydroxy iron material in depotassified mica (Foscolos et al., 1977).

Although Taylor (1987) postulates that the "soil-like features" of this unit formed after the unit was buried and are therefore not pedogenic, his quantitative laboratory data are consistent with the conclusion that the unit is a buried paleosol (Fig. 9). Clay and dithionite-, oxalate- and pyrophosphateextractable iron and aluminum are concentrated in the paleoargillic horizon of the paleosol, whereas percentages of $\mathrm{CaCO}_{3}$, anorthite (calcium feldspar) and heavy minerals in the sand fraction, and total phosphorous decrease through the profile, as would be expected in a soil exposed to pedogenic processes over time. In addition, his micromorphological analyses indicate reorganization of plasma such that sesqui-argillans are common in the upper part and voidargillans predominate in the lower portions.

\section{GENESIS OF PALEOSOLS}

As noted, Taylor's (1987) assertion that the pre-Wisconsinan profile on Cloudy Ridge is not a paleosol because it's "soil-like features" formed during and after burial is disproven by the fact that relict paleosols with very similar features occur at the surface of several Flaxville bench remnants to the south (Figs. 1 and 2). Thickness, degree of clay buildup, rubification, and clay mineral alteration of the paleosols capping Kennedy Drift diamictons suggest their considerable antiquity and probable formation under climates significantly different from today's (Karlstrom, 1991). Paleoargillic horizons on Milk River and Cloudy Ridges range between 135 and $369 \mathrm{~cm}$ thick, are oxidized to yellowish red to strong brown colors, have up to $18 \%$ more (absolute) clay than underlying horizons, and include mixed-layer kaolinite-illite and chlorite-vermiculite clays in addition to inherited illite, kaolinite, and chlorite. With a few exceptions (Foscolos, 1977; Duk-Rodkin et al., 1996), paleosols of similar antiquity have not been described elsewhere in Canada. However, similar paleosols have been identified in the U.S. Rocky Mountains (Hunt and Sokoloff, 1950; Horberg, 1956; Karlstrom, 1991).

Properties of the paleosols differ strikingly from those of typical post-Wisconsinan soils in the region, which are much thinner, less oxidized, and generally lack argillic horizons altogether (Table I). A soil developed in Wisconsinan alpine lateral moraine under forest vegetation $0.4 \mathrm{~km}$ south of Saint Mary, Montana (NE1/4, NW1/4, Section 3, T34N, R14W, Saint Mary 


\section{MILK RIVER RIDGE}

E Horizon

\section{$\AA \stackrel{7}{1} \stackrel{10}{\perp} \quad 14$}

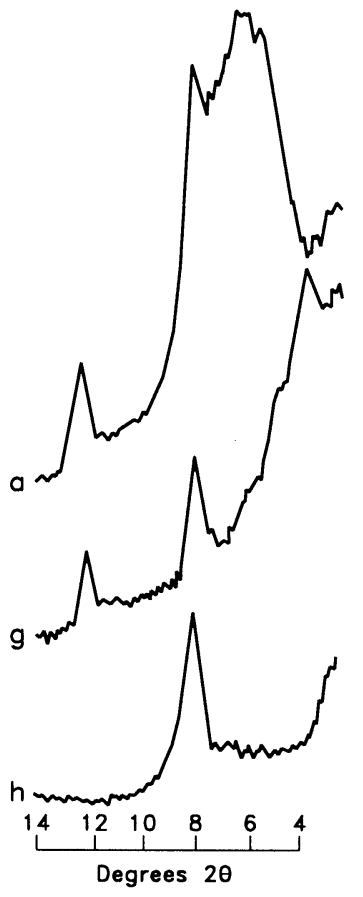

Btb2 Horizon

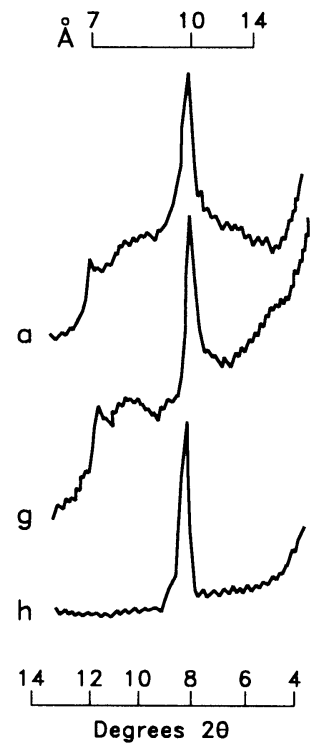

Bt3 Horizon

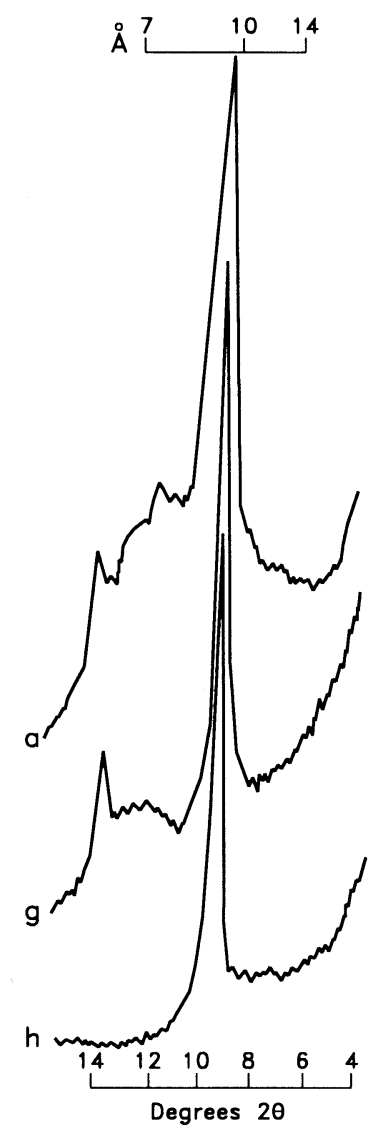

Btb4 Horizon

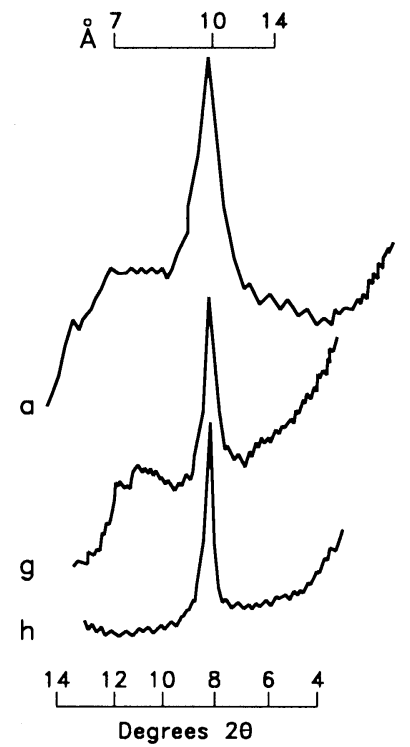

W4 Horizon

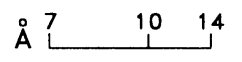

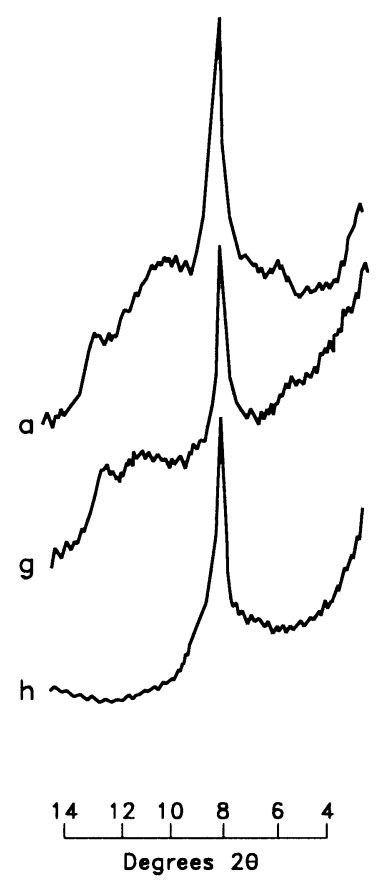

$\mathrm{Cb}$ Horizon

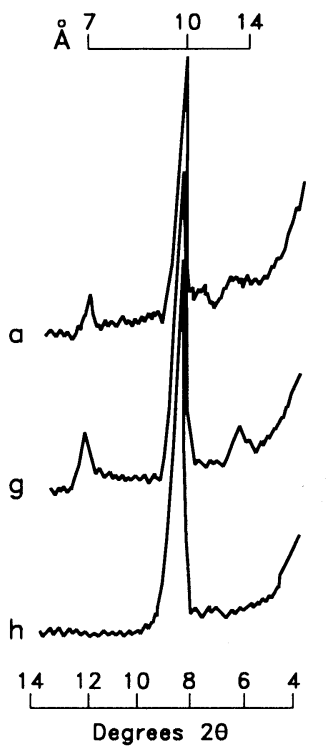

FIGURE 7. X-ray diffraction patterns for selected horizons of paleosols on Milk River Ridge. en provenance du Milk River Ridge. 


\section{CLOUDY RIDGE}

A1 Horizon

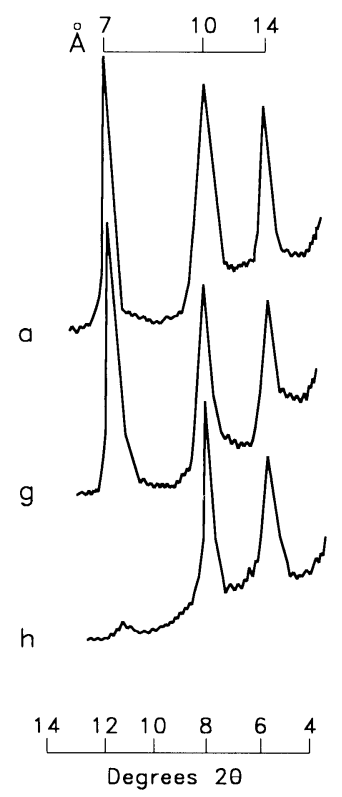

2Btb2 Horizon

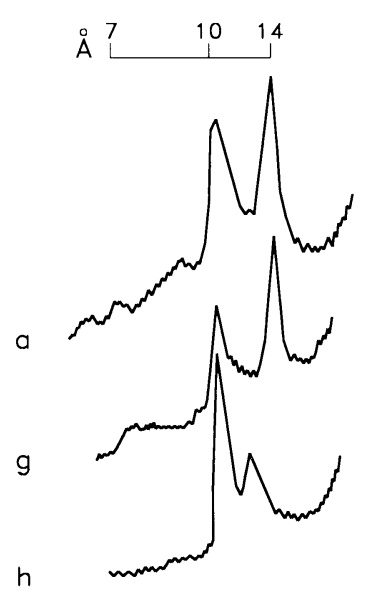

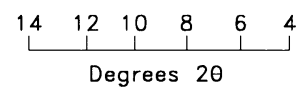

2Bwb2 Horizon

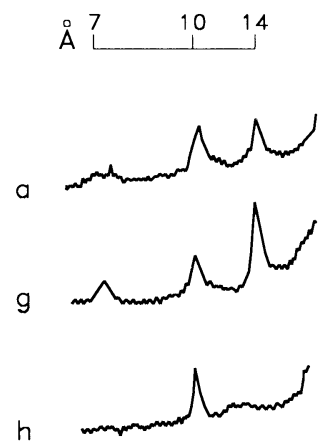

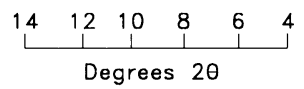

FIGURE 8. X-ray diffraction patterns for selected horizons of paleosol on Cloudy Ridge.

Quadrangle, USA), for example, is a Typic Cryochrept (Soil Survey Staff, 1975) with a 6-cm thick, very dark gray brown (10YR 3/2 dry) A horizon, an 8-cm thick, incipient light gray brown (10YR 6/2 dry) E horizon, a 13-cm thick, pale brown (10YR 6/3 dry) cambic (Bw) horizon and a 37-cm thick, brown (10YR 5/3 moist) Bk horizon (Table II).

Classification of the paleosols is problematic because they are undoubtedly polygenetic (have been subject to numerous climatic regimes) and have probably undergone some diagenetic alterations, both in buried and surface situations, particularly of reversible soil properties such as $\mathrm{pH}$ and organic matter content (Yaalon, 1971). Hence, although in many respects the paleosols resemble Ultisols (low base-status forest soils), they should probably be classed as Paleudalfs, or ancient high-base-status forest soils formed under a humid climate, based on properties such as percent base saturation and the persistence of relatively weatherable minerals such as mica (Soil Survey Staff, 1975). Paleudalfs typically form under mesic to thermic climatic regimes, with mean annual soil temperature between 8 to 15 , and 15 to $22^{\circ} \mathrm{C}$, respectively (Soil Survey Staff, 1975). Properties of the paleosols also resemble those of fersiallitic or fersiallitic brown soils which typically form under Mediterranean-type climates with relatively hot, dry summers and cool moist winters (Duchaufour, 1977).

No similar soil types are described in the Canadian System of Soil Classification (Canada Soil Survey Committee, 1978). However, Foscolos et al. (1977) classify the similar "pre-Reid" paleosol (early Pleistocene) in the Central Yukon as a Luvisol (the Canadian Classification equivalent to Alfisol) and make similar paleoclimatic interpretations.
Diagrammes de diffractométrie $X$ de certains horizons de paléosols, en provenance du Cloudy Ridge.

\section{PALEOMAGNETIC ANALYSIS}

\section{METHODS}

Oriented samples were collected in fine-grained pockets of sediments within the diamictons on Milk River Ridge and Cloudy Ridge. Cores were drilled from pebble-free zones within the cemented diamicton (calcrete) on Cloudy Ridge. Seven to 10 samples were collected in a vertical sequence with an average spacing of $10 \mathrm{~cm}$. Sediments were collected by cleaning the exposure to a vertical face and inserting plastic cylinders ( $2.5 \mathrm{~cm}$ diameter) horizontally, and calcretes were drilled using a gas-powered portable water-cooled drill. Field orientations of the samples were measured using a magnetic compass. Remanence measurements were made on a AGICO JR-5A spinner magnetometer. Stepwise alternating field demagnetization was carried out using a Schonstedt GSD-5 with tumbler in peak fields up to $100 \mathrm{mT}$. Samples were demagnetized using 5-10 steps, and directions were determined by principle component analysis (Kirshvink, 1980).

Samples from the Milk River Ridge site were collected for paleomagnetic analysis at about $70 \mathrm{~cm}$ depth in the upper paleosol/diamicton and at about 8 to $9 \mathrm{~m}$ depth in a pocket of fine sediments within the lower diamicton. The samples from the upper paleosol/diamicton are characterized by a single component in a typical normal polarity direction- northerly and down-dipping (Table II, Fig. 10a). The lower unit reveal a high coercivity component with down-dipping inclination (streaked from shallow to deep) and anomalous southerly declination (Table II, Fig. 11). This unit has an isotropic magnetic grain/pebble fabric. 

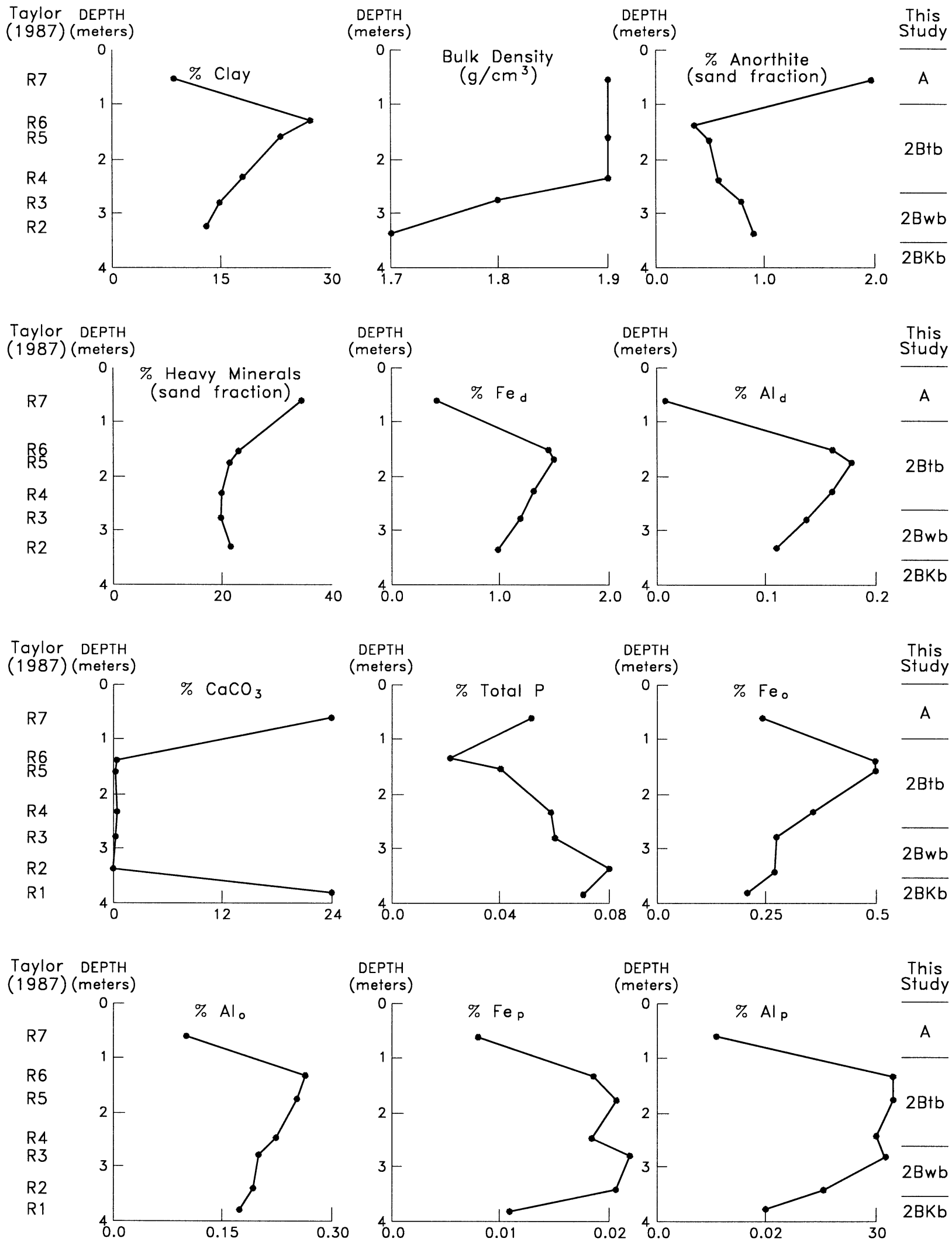

A

2Btb

$2 B w b$

$2 \mathrm{BKb}$

FIGURE 9. Plots of percent clay, anorthite, heavy minerals, and dithionite-, oxalate-, and pyrophosphate-extractable iron and aluminum, and bulk density with depth in Cloudy Ridge paleosol (data from Taylor, 1987). R1 through R7 are horizon designations.

Diagrammes des pourcentages d'argile, d'anorthite, de minéraux lourds, du dithionite, de l'oxalate et du pyrophosphate extractibles $d u$ fer et de l'aluminium, ainsi que la densité apparente selon la profondeur dans le paléosol du Cloudy Ridge (données de Taylor, 1987). $R 1$ à $R 7$ désignent des horizons. 
FIGURE 10. Orthogonal plots of typical demagnetization behavior. The closed (open) symbols refer to the horizontal (vertical) projection of the magnetic remanence vector after each step, in $\mathrm{mT}$ for alternating field demagnetization: a) simple unicomponent magnetization in the upper Milk River paleosol/diamicton; b) unicomponent magnetization in the Cloudy Ridge calcrete; c) lightning-affected magnetization from the Cloudy Ridge paleosol.

Diagrammes orthogonaux illustrant le comportement caratéristique de la démagnétisation. Les cercles blancs correspondent à la projection horizontale (verticale) du vecteur de magnétisme rémanent après chacune des étapes, en $m T$ pour la démagnétisation alternative : a) magnétisme à composante unique simple dans le diamicton/paléosol de la partie supérieure de la Milk River; magnétisme à composante unique dans les encroûtements calcaires du Cloudy Ridge; c) magnétisme sensible à la foudre en provenance du paléosol du Cloudy Ridge.

Samples from the argillic horizon within the Cloudy Ridge paleosol (about $1 \mathrm{~m}$ depth) and the underlying calcrete (about 7 and $11 \mathrm{~m}$ depth) were sampled for paleomagnetic analysis. The calcrete records a simple, well-behaved normal polarity (Fig. 10b), whereas the paleosol records a lightning-affected normal polarity (Fig. 10c), as indicated by the strong but easily-demagnitized overprints in widely-varying directions (mean directions given in Table II and Fig. 11).

\section{PALEOMAGNETISM OF DIAMICTON/PALEOSOL/CALCRETE UNITS}

The two Milk River Ridge diamicton/paleosol units and the Cloudy Ridge calcrete/diamicton/paleosol units are all normally magnetized (Table II, Figs. 2 and 11). The magnetization of the lower paleosol at Milk River Ridge has a southerly direction (smear), which may be an artifact of the depositional process (glacier advance from the south) or possibly by chemical remagnetization during soil formation, but is nevertheless normal. The upper paleosol/diamicton at Cloudy Ridge has been overprinted by lightning, but upon magnetic cleaning by alternating field demagnetization and fitting of great circles to the stepwise cleaned directions (Kirshvink, 1980), reveals a normal magnetization. The sediments of the normally magnetized units at both sites are of glacial origin and are correlated with upper normally magnetized units of the Kennedy Drift, described previously (Cioppa et al., 1985; Barendregt et al., 1991). The Cloudy Ridge till and the upper Milk River Ridge till are assigned to the Brunhes Normal Polarity Chron (0.78 ka to present). The greater thickness and degree of weathering of the lower Milk River Ridge till suggest that it was deposited earlier during the Bruhnes Chron or alternatively, during the Olduvai (1.98-1.76 Ma) Normal Subchron or possibly the Gauss Normal Polarity Chron (3.6 to 2.6 Ma).

\section{CONCLUSION}

Pebble fabric and sedimentological properties of diamicton units on Cloudy Ridge and Milk River Ridge suggest they are primarily of glacial rather than colluvial origin. Fabrics suggest that glacier flow across these surfaces was roughly orthogonal to the mountain front. Numerous properties, including thickness, degree of leaching and oxidation, concentration of clay, iron and aluminum, and extent of clay mineral alteration and depletion of anorthite, strongly suggest that

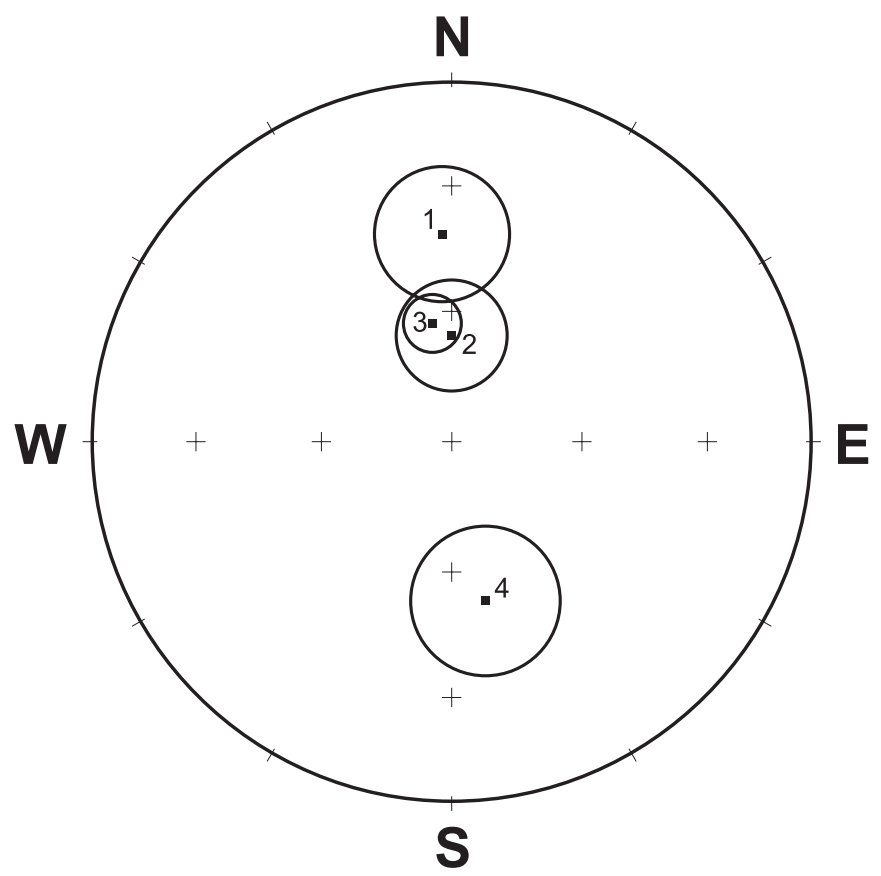

FIGURE 11. Stratigraphic plot of unit means (solid squares) plotted on a lower hemisphere stereographic projection and their associated $95 \%$ confidence intervals. The number labels are: 1) Cloudy Ridge paleosol (lightning affected); 2) Cloudy Ridge till (cemented and of Cordilleran provenance); 3) upper Milk River Ridge paleosol in upper till; and 4) lower Milk River Ridge paleosol in lower till.

Graphique stratigraphique des moyennes unitaires (carrés noirs) reportées sur l'hémisphère inférieur d'une projection stéréographique avec des intervalles de confiance de $95 \%$. Les ensembles numérotés représentent : 1) le paléosol de Cloudy Ridge (sensible à la foudre); 2) le till de Cloudy Ridge (cimenté et d'origine cordillérenne); 3) le paléosol supérieur du Milk Rive Ridge issu du till supérieur; 4) le paléosol inférieur du Milk River Ridge issu du till inférieur. 
weathering zones capping the tills are paleosols which formed over long time periods (hundreds of thousands of years) under climates probably warmer and more equable than the present. The fact that nearly identical paleosols occur both at the surface and in buried situations indicate that their properties are derived from pedogenic rather than diagenetic processes and that they are ancient soils related to landscapes of the past. Paleoclimatic evidence elsewhere, including paleobotanical markers, also indicate that early and middle Quaternary interglacials were considerably warmer and moister than the present climate (Frakes, 1979).

Paleomagnetic data indicate all three units have normal polarity. The upper tills and associated paleosols on Cloudy Ridge and Milk River Ridge resemble the upper units on other nearby Flaxville surface remnants (Cioppa et al., 1995) and most likely were deposited during the middle or early portion of the Brunhes Normal Chron (780 ka to present). The lower till on Milk River Ridge may have been deposited during the early Brunhes Chron. However, based on its great thickness and degree of weathering, it may have been deposited during the Olduvai (1.96 to $1.76 \mathrm{Ma}$ ) Normal Subchron or possibly even the Gauss Normal Polarity Chron (3.6 to 2.6 Ma).

\section{ACKNOWLEDGMENTS}

We would like to thank Barb Byron for assistance in the field and for running the pebble fabrics on computer program and Dr. S. Hicock (Department of Earth Science, University of Western Ontario) for valuable discussions in the field. Drs. D. J. Easterbrook and A. Duk-Rodkin gave valuable suggestions to improve the manuscript. Linda Marston drafted the figures.

\section{REFERENCES}

Alden, W. C., 1932. Physiography and glacial geology of the northern Great Plains. U.S. Geological Survey Professional Paper 174, Washington, D.C. $133 \mathrm{p}$.

Alden, W. C. and Stebinger, E., 1913. Pre-Wisconsin glacial drift in the region of Glacier National Park, Montana. Geological Society of America Bulletin, 24 529-572.

Andrews, J. T., 1971. Techniques of till fabric analysis. British Geomorphologica Research Group Technical Bulletin, 6, $43 \mathrm{p}$

Barendregt, R. W., Enkin, R., Duk-Rodkin, A. and Baker, J., 1996. Paleomagnetic evidence for Late Cenozoic glaciations in the Mackenzie Mountains of the Northwest Territories, Canada. Canadian Journal of Earth Sciences, 33 896-903.

Barendregt, R. W., Irving, E. and Karlstrom, E. T., 1991. Paleomagnetism of Quaternary and Late Tertiary sediments on Mokowan Butte, southwestern Alberta. Canadian Journal of Earth Sciences, 28: 1956-1964.

Barendregt, R. W., Vincent, J.-S., Irving, E. and Baker, J., 1998. Magnetostratigraphy of Quaternary and late Tertiary sediments on Banks Island, Canadian Arctic Archipelago. Canadian Journal of Earth Sciences, 35: 147-161.

Birkeland, P.W., 1999. Soils and Geomorphology. Oxford University Press, New York, $430 \mathrm{p}$.

Blackwelder, E., 1928. Mudflow as a geologic agent in semiarid mountains. Geological Society of America Bulletin, 39: 307-340.

Boulton, G. S., 1968. Flow tills and related deposits on some Vestspitsbergen glaciers. Journal of Glaciology, 6: 717-735.

Boulton, G. S. and Dobbie, K. E., 1993. Consolidation of sediments by glaciers: relations between sediment glaciotectonics, soft-bed glacier dynamics and subglacial groundwater flow. Journal of Glaciology, 39: 26-44.
Canada Soil Survey Committee, 1978. The Canadian System of Soil Classification. Research Branch Canada Department of Agriculture, Publication 1646, Ottawa, $164 \mathrm{p}$

Cioppa, M. T., Karlstrom, E. T., Irving, E. and Barendregt, R. W., 1995 Paleomagnetism of tills and associated paleosols in southwestern Alberta and northern Montana: Evidence for Late Pliocene-Early Pleistocene glaciations. Canadian Journal of Earth Sciences, 32: 555-564.

Daly, R. A., 1912. Geology of the North American Cordillera at the fourty-ninth parallel. Geological Survey of Canada, Memoir 38, Ottawa, $857 \mathrm{p}$.

Dowdeswell, J. A., Hambrey, M. J. and Wu, R., 1985. A comparison of clast fabric and shape in Late Precambrian and modern glacigenic sediments. Journal of Sedimentary Petrology, 55: 691-704.

Dowdeswell, J. A. and Sharp, M. J., 1986. Characterization of pebble fabrics in modern terrestrial glacigenic sediments. Sedimentology, 33: 699-710.

Dreimanis, A., 1962. Quantitative gasometric determination of calcite and dolomite by using Chittick apparatus. Journal of Sedimentary Petrology, 2 : 520-529

1989. Tills: Their genetic terminology and classification, p. 17-84. In R.P. Goldthwait and C.L. Matsch, eds., Genetic Classification of Glacigenic Deposits. Balkema, Rotterdam, $350 \mathrm{p}$.

1993. Downward injected till wedges and upward injected till dikes. Sveriges Geologiska Undersokning, Ser, CA 81: 91-96.

Duchaufour, P. 1977. Pedology: Pedogenesis and Classification (translated by T.R. Paton). Allen and Unwin, London, $448 \mathrm{p}$

Duk-Rodkin, A., Barendregt, R. W., Tarnocai, C. and Phillips, F. M., 1996. Late Tertiary to Late Quaternary record in the Mackenzie Mountains, Northwest Territories, Canada: Stratigraphy, paleosols, paleomagnetism, and chlorine36. Canadian Journal of Earth Sciences, 33: 875-895.

Foscolos, A. E., Rutter, N. W. and Hughes, O. L. 1977. The use of pedological studies in interpreting the Quaternary history of Central Yukon Territory. Geological Survey of Canada, Bulletin 271, $48 \mathrm{p}$.

Froese, D. G., Barendregt, R.W., Enkin, R. J. and Baker, J., 2000. Paleomagnetic evidence for late Pliocene-early Pleistocene glaciation in the Klondike area, Yukon Territory. Canadian Journal of Earth Sciences, 37: 863-877.

Frakes, L. A., 1979. Climates throughout Geologic Time. Elsevier Scientific Publishing Company, Amsterdam, $310 \mathrm{p}$

Guthrie, R. L. and Witty, J. E., 1982. New designations for soil horizons and layers and the new Soil Survey Manual. Soil Science Society of America Journal, 46: 443-444.

Ham, N. R. and Mickelson, D. M., 1994. Basal till fabric and deposition at Burroughs Glacier, Glacier Bay, Alaska. Geological Society of America Bulletin, 106: 1552-1559.

Harden, J. W., 1982. A quantitative index of soil development from field descriptions: Examples from a chronosequence in central California. Geoderma, 28: $1-28$

Harris, S. A., 1972. The nature and use of till fabric, p. 45-65. In E. Yatsu and A Falcones, eds., Research Methods in Pleistocene Geomorphology, Proceedings, 2nd Guelph Symposium on Geomorphology, 1971. Geo Abstracts, Norwich, 285 p.

Hart, J. K., 1994. Till fabric associated with deformable beds. Earth Surface Processes and Landforms, 19: 15-32.

Hicock, S. R., 1991. On subglacial stone pavements in till. Journal of Geology, 99: 607-619.

Horberg, L., 1954. Rocky Mountain and continental Pleistocene deposits in the Waterton region, Alberta. Geological Society of America Bulletin, 65: 10931150

1956. A deep profile of weathering on pre-Wisconsin drift in Glacier National Park. Journal of Geology, 64: 210-218.

Hunt, C.B. and Sokoloff, V.P. 1950. Pre-Wisconsin soil in the Rocky Mountain region: A progress report. U.S. Geological Survey Professional Paper 221G, Washington, D.C., 109-123.

Jackson, M. L., 1965. Clay transformation in soil genesis during the Quaternary. Soil Science, 99: 15-22 
Jackson, L. E., Jr., Barendregt, R. W., Baker, J. and Irving, E., 1996. Early Pleistocene volcanism and glaciation in Central Yukon: A new chronology from field studies and paleomagnetism. Canadian Journal of Earth Sciences, 33: 904-916.

Jackson, L. E., Jr., Phillips, F. M. and Little, E. C., 1999. Cosmogenic 36Cl dating of the maximum limit of the Laurentide Ice Sheet in southwestern Alberta. Canadian Journal of Earth Sciences, 36: 1347-1356.

Johnson, M., 1990. Fabric and origin of diamictons in end moraines, Animas River Valley, Colorado, U.S.A. Arctic and Alpine Research, 22: 14-25.

Kamb, W. B., 1959. Ice petrofabric observations from Blue Glacier, Washington in relation to theory and experiment. Journal of Geophysical Research, 64 1891-1901.

Karlstrom, E. T., 1981. Late Cenozoic soils of the Glacier and Waterton Parks area, northwestern Montana and southwestern Alberta, and paleoclimatic implications. Ph.D. dissertation, Department of Geography, The University of Calgary, Calgary, $358 \mathrm{p}$.

1987. Stratigraphy and genesis of five superposed paleosols in preWisconsinan drift on Mokowan Butte, southwestern Alberta. Canadian Journal of Earth Sciences, 24: 2235-2253.

1988. Multiple paleosols in pre-Wisconsinan drift, northwestern Montana and Southwestern Alberta. Catena, 15: 147-178.

1991. Paleoclimatic significance of Late Cenozoic paleosols east of Waterton-Glacier Parks, Alberta and Montana. Palaeogeography, Palaeoclimatolgy, and Palaeoecology, 85: 71-100.

2000. Fabric and origin of multiple diamicts within pre-Illinoian Kennedy Drift east of Waterton-Glacier National Peace Park, Montana and Alberta Geological Society of America Bulletin, 112: 1496-1506.

Kirschvink, J. L., 1980. The least-squares line and plane and the analysis of paleomagnetic data. Geophysical Journal of the Royal Astronomical Society, 62: 699-718.

Lawson, D. E., 1979. A comparison of the pebble orientations in ice and deposits of the Matanuska Glacier, Alaska. Journal of Geology, 87: 629-645.

1981, Distinguishing characteristics of diamictons at the margin of the Matanuska Glacier, Alaska. Annals of Glaciology, 2: 78-84.

Levine, E. R. and Ciolkosz, E. J., 1983. Soil development in tills of various ages in northeastern Pennsylvania. Quaternary Research, 19: 85-99.

Lindsay, J. F., 1968. The development of clastic fabric in mudflows. Journal of Sedimentary Petrology, 38: 1243-1253.

Little, E. C., 1995. A single-maximum-advance hypothesis of continental glaciation restricted to the Late Wisconsinan, southwestern Alberta. M.Sc. Thesis, Department of Earth Sciences, The University of Western Ontario, London, $229 \mathrm{p}$.

1998. Quaternary geology and terrain inventory, Eastern Cordillera NATMAP Project. Report 3: Two continental glacial advances in Waterton and Cardston map areas, Alberta. Current Research, Geological Survey of Canada, Paper 95-A: 177-182.

Mark, D. M., 1973. On the interpretation of till fabrics. Geology, 2: 101-104.

Mehra, O. P. and Jackson, M. L., 1960. Iron oxide removal from soils and clays by a dithionite-citrate system buffered with sodium bicarbonate, p. 317-327. In National Conference on Clays and Clay Minerals. Pergamon, London, 369 p.
Millot, G., 1970. Geology of Clays. Springer-Verlag, New York, 429 p.

Piper, C. S., 1950. Soil and Plant Analysis. Hassel Press, Adelaide, 368 p.

Richmond, G. M., 1957. Three pre-Wisconsin glacial stages in the Rocky Mountain region. Geological Society of America Bulletin, 68: 239-262.

1965. Glaciation of the Rocky Mountains, p. 217-231. In H. E. Wright and D. G. Frey, eds., The Quaternary of the United States. INQUA VIIth Congress, Princeton University Press, $922 \mathrm{p}$.

1986. Stratigraphy and correlation of glacial deposits of the Rocky Mountains, the Colorado Plateau and the Ranges of the Great Basin, p. 99128. In V. Sibrava, D.Q. Bowen and G.M. Richmond, eds., Quaternary Glaciations in the Northern Hemisphere. Report of the International Geological Correlation Programme Project 24, Permagon Press, Oxford, $514 \mathrm{p}$.

Ryder, J. M., 1981. Biophysical resources of the East Kootenay area: terrain. APD Bulletin 7, British Columbia Ministry of Environment, Victoria, $152 \mathrm{p}$.

Shackleton, N. J., Berger, A. and Peltier, W. R., 1990. An alternative astronomical calibration of the lower Pleistocene time scale based on ODP site 677. Transactions of the Royal Society of Edinburgh: Earth Sciences, 81: 251 261.

Sharp, M. J., 1982. Modification of clasts in lodgement till by glacial erosion. Journal of Glaciology, 28: 239-258.

Sims, J. R. and Haby, V. A., 1971. Simplified colorimetric determination of soil organic matter. Soil Science, 112: 137-141.

Soil Survey Staff, 1975. Soil Taxonomy: A Basic System of Soil Classification for Making and Interpreting Soil Surveys. Soil Conservation Service, U.S. Department of Agriculture Handbook 436, U.S. Government Printing Office, Washington, D.C., $754 \mathrm{p}$.

Spooner, I. S., Osborn, G. D., Barendregt, R. W. and Irving, E., 1995. A record of Early Pleistocene glaciation on the Mount Edziza Plateau, northwestern British Columbia. Canadian Journal of Earth Sciences, 32: 2046-2056.

Stalker, A. MacS. and Harrison, J. E., 1977. Quaternary glaciation of the Wateron-Castle River region of Alberta. Bulletin of Canadian Petroleum Geologists, 25: 882-906.

Taylor, W. S., 1987, Paleopedology in the Cypress Hills and Waterton Areas, Alberta. University of Alberta, M.Sc. Thesis, Edmonton, 140 p.

Van Houten, F. B., 1957. Appraisal of the Ridgway and Gunnison "tillites", southwestern Colorado. Geological Society of America Bulletin 68: 383-388.

Van Vliet, B. and Langhor, R., 1981. Correlation between fragipans and permafrost with special reference to silty Weischselian deposits in Belgium and northern France. Catena, 8: 137-154.

Wagner, W. P., 1966. Correlation of Rocky Mountain and Laurentide glacial chronologies in southwestern Alberta, Canada. Ph.D. thesis, University of Michigan, Ann Arbor, 141 p.

Willis, B., 1902. Stratigraphy and structure, Lewis and Livingstone Ranges, Montana. Geological Society of America Bulletin, 13: 305-352.

Yaalon, D. L., 1971. Soil forming processes in time and space. p. 29-39. In D.L. Yaalon, ed., Paleopedology. Israel University Press, Jerusalem, 350 p. 